\title{
El Niño evolution during the Holocene revealed by a biomarker rain gauge in the Galápagos Islands
}

\author{
Zhaohui Zhang ${ }^{\mathrm{a}, \mathrm{b}, *}$, Guillaume Leduc ${ }^{\mathrm{c}, \mathrm{d}}$, Julian P. Sachs ${ }^{\mathrm{a}}$ \\ a University of Washington, School of Oceanography, Seattle, WA 98195, USA \\ b State Key Laboratory for Mineral Deposits Research (Nanjing University), School of Earth Sciences and Engineering, Nanjing University, 22 Hankou Road, \\ Nanjing, 210093, China \\ c Kiel University, Institute of Geosciences, Kiel, Germany \\ d CEREGE, UMR7330, Aix-Marseille Université, CNRS, IRD, Europôle de l'Arbois, BP80, 13545, Aix-en-Provence Cedex 4, France
}

\section{A R T I C L E I N F O}

\section{Article history:}

Received 3 October 2013

Received in revised form 6 July 2014

Editor: J. Lynch-Stieglitz

\section{Keywords:}

ENSO

Holocene

Galápagos

biomarker

hydrogen isotope

\begin{abstract}
A B S T R A C T
The El Niño-Southern Oscillation (ENSO) represents the largest perturbation to the climate system on an inter-annual time scale, but its evolution since the end of the last ice age remains debated due to the lack of unambiguous ENSO records lasting longer than a few centuries. Changes in the concentration and hydrogen isotope ratio of lipids produced by the green alga Botryococcus braunii, which blooms during El Niño rains in the Galápagos Islands, indicate that the early Holocene (9200-5600 yr BP) was characterized by alternating extremes in the intensity and/or frequency of El Niño events that lasted a century or more. Our data from the core of the ENSO region thus calls into question earlier studies that reported a lack of El Niño activity in the early Holocene. In agreement with other proxy evidence from the tropical Pacific, the mid-Holocene (5600-3500 yr BP) was a time of consistently weak El Niño activity, as were the Early Middle Ages ( $1000-1500$ yr BP). El Niño activity was moderate to high during the remainder of the last 3500 years. Periods of strong or frequent El Niño tended to occur during peaks in solar activity and during extended droughts in the United States Great Plains linked to La Niña. These changing modes of ENSO activity at millennial and multi-centennial timescales may have been caused by variations in the seasonal receipts of solar radiation associated with the precession of the equinoxes and/or changes in solar activity, respectively.
\end{abstract}

(C) 2014 Elsevier B.V. All rights reserved.

\section{Introduction}

The tropical Pacific atmosphere-ocean system that drives the El Niño-Southern Oscillation (ENSO) is anticipated to change in response to increased radiative forcing from anthropogenic greenhouse gas emissions, with global repercussions (Collins et al., 2010; Pierrehumbert, 2000). Yet the nature and sensitivity of this response is not well understood (DiNezio et al., 2009), partly due to an incomplete knowledge of the underlying climate physics and a lack of paleoclimate data bearing on ENSO variations through time.

Documenting how ENSO evolved through the Holocene in response to known climate forcings is hence crucial for validating model projections of ENSO in the future. Though a wealth of rainfall reconstructions from sedimentary sequences in the

\footnotetext{
* Corresponding author. Present address: School of Earth Sciences and Engineering, Nanjing University, 22 Hankou Road, Nanjing, 210093, China.

E-mail address: zhaohui@nju.edu.cn (Z. Zhang).
}

tropical Pacific has been produced in an effort to characterize ENSO during the Holocene (see Braconnot et al., 2012 and references therein), those studies remain inconclusive for two reasons. First, the oscillatory nature of ENSO between El Niño and La Niña conditions (Clement et al., 1999) can dampen the signal of inter-annual climate extremes in slowly accumulating sedimentary records since the two opposing modes tend to have counteracting effects on sea surface temperature (SST) reconstructions that average over decades to millennia. Second, it can be difficult to attribute a sedimentary signal unambiguously to one climate phenomenon or the other in locations influenced by both ENSO and seasonal migrations of the Intertropical Convergence Zone (ITCZ) (Braconnot et al., 2012; Koutavas and Joanides, 2012; Leduc et al., 2009a, 2009b; Thirumalai et al., 2013). Corals have sub-annual resolution adequate to reconstruct ENSO, but as they are short lived the most comprehensive composite coral record to date is too under-sampled to document the complete Holocene time period (Cobb et al., 2013). New continuous sedimentary archives and climate proxies that can be unambiguously attributed to ENSO are needed. 
a

Annual Total Precipitation (mm)
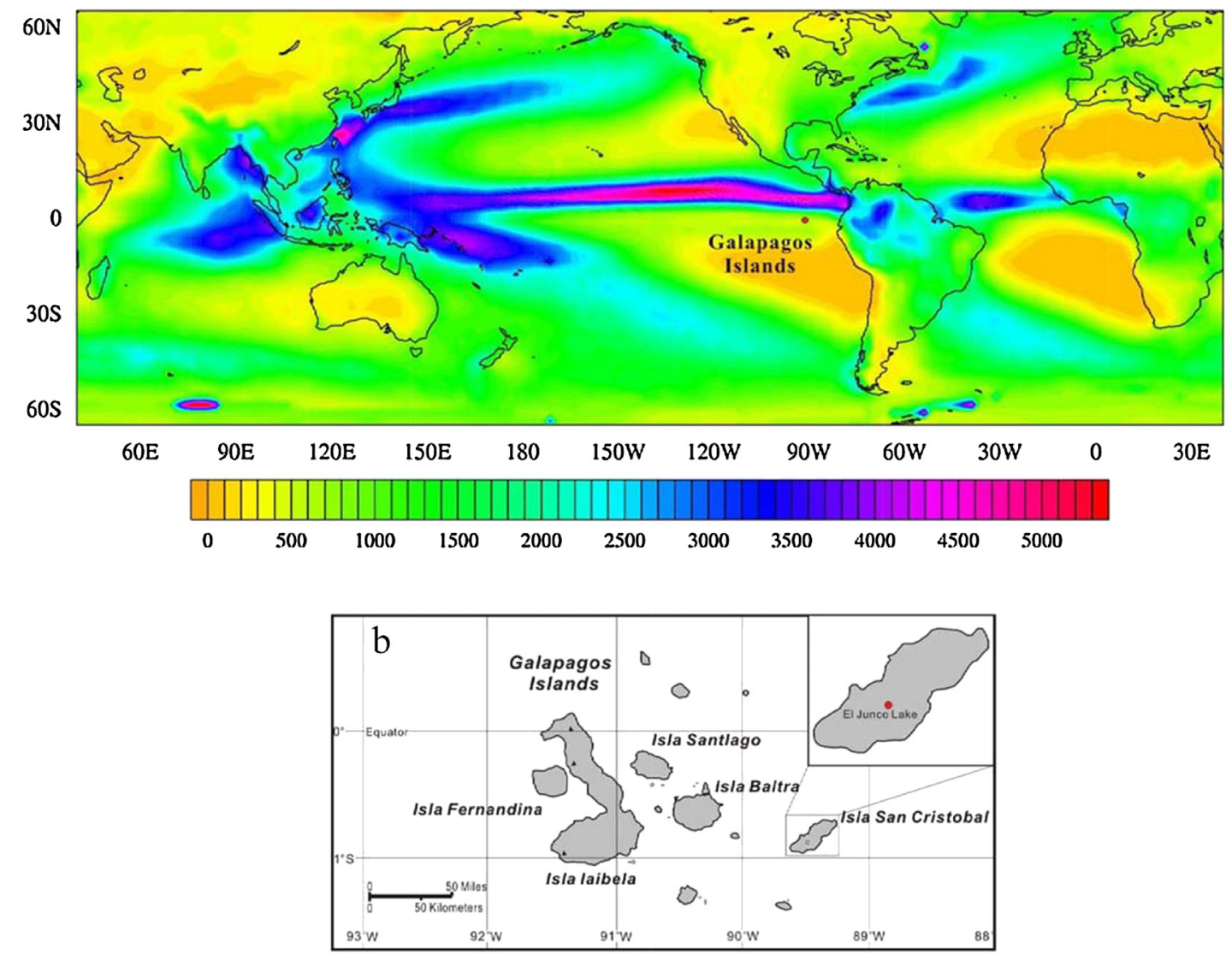

Overflow Channel

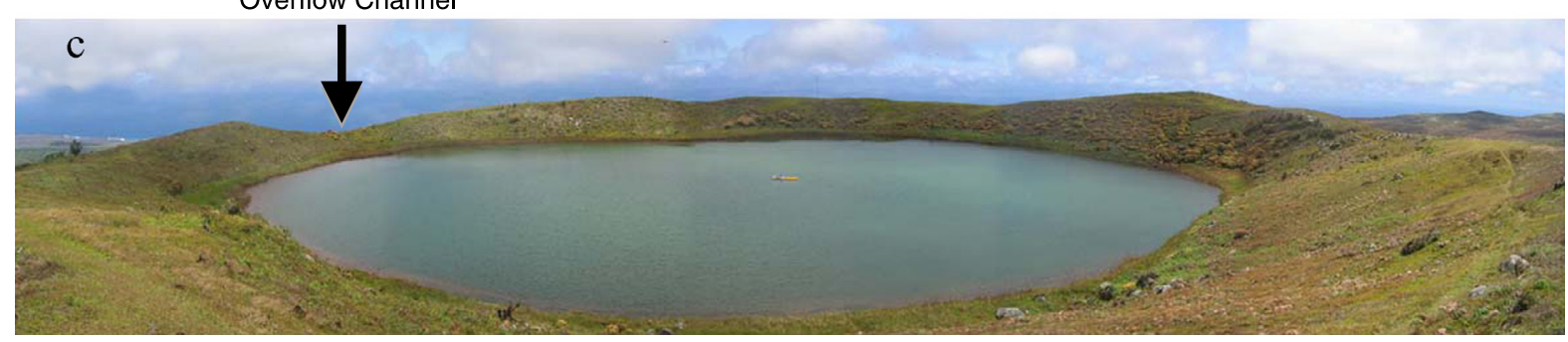

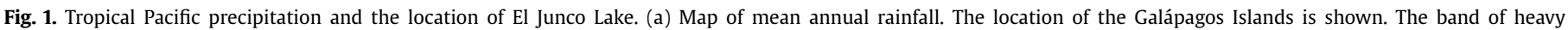

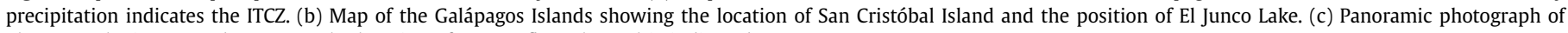
El Junco Lake in September, 2004. The location of an overflow channel is indicated.

Located on the equator $\sim 1000 \mathrm{~km}$ west of Ecuador, the Galápagos archipelago lies south of the modern mean-annual ITCZ position and far from continental climate effects that can complicate the elucidation of coupled ocean-atmosphere processes in paleoclimate records (Fig. 1a). The seasonal climate is characterized by a warm, wet season from January to June, when the ITCZ is nearest to the equator, and a cool, dry season from July to December when the ITCZ is at its northernmost location (Fig. 2). At the height of the warm season in March, the ITCZ splits into northern and southern branches at about the equator, resulting in a bimodal distribution of rainfall with maxima at about $5^{\circ} \mathrm{N}$ and $5^{\circ} \mathrm{S}$, and a relatively dry equatorial zone and Galápagos archipelago during normal years (Gu et al., 2005) (Fig. 2). The persistence of the equatorial cold tongue is the key to this double ITCZ, which vanishes during El Niño events when an intense rainfall band extends continuously from $5^{\circ} \mathrm{S}$ to $5^{\circ} \mathrm{N}$ (Gu et al., 2005). El Niño years are thus associated with surges in rainfall in the Galápagos that can exceed rainfall in non-El Niño years by an order of magnitude (Fig. 3).
The only permanent freshwater lake in the Galápagos, El Junco $\left(0.30^{\circ} \mathrm{S}, 91.00^{\circ} \mathrm{W}\right)$, lies $670 \mathrm{~m}$ above sea level in the closed caldera of an extinct volcano in the highlands of San Cristóbal Island (Fig. 1b, c). With a diameter of $280 \mathrm{~m}$ and a depth of $6 \mathrm{~m} \mathrm{El}$ Junco collects rainwater from a very small catchment $\left(0.13 \mathrm{~km}^{2}\right)$, and is enshrouded in low-elevation stratus clouds (known locally as garúa) for much of the year. An overflow channel $3 \mathrm{~m}$ deep and $2 \mathrm{~m}$ wide is evident in the lowest part of the rim (Fig. 1c, indicated by an arrow) (Colinvaux, 1972), but as of this time we are unaware of any confirmed observations of water flowing through the channel. Apart from this overflow and possible seepage through the rim, the lake basin is closed (endorheic).

In a companion paper, Atwood and Sachs (2014) construct an idealized model of the hydrologic balance of El Junco Lake that takes into consideration precipitation, evaporation, seepage, and overflow. They find that the isotope mass balance of the Lake during El Niño warm events is, to a first order, driven by anomalously high precipitation rates rather than by water loss via evaporation, overflow or seepage (Atwood and Sachs, 2014). 


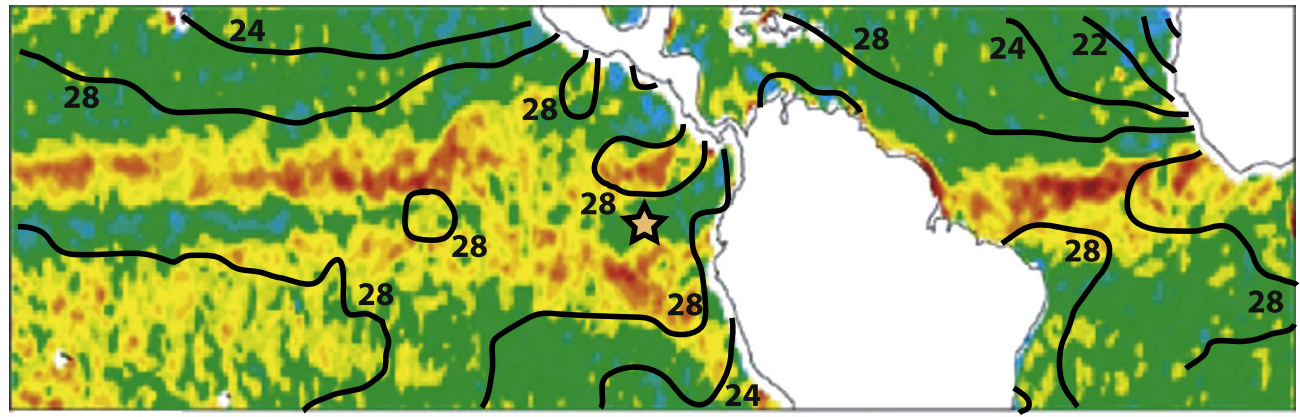

\section{March 2001}

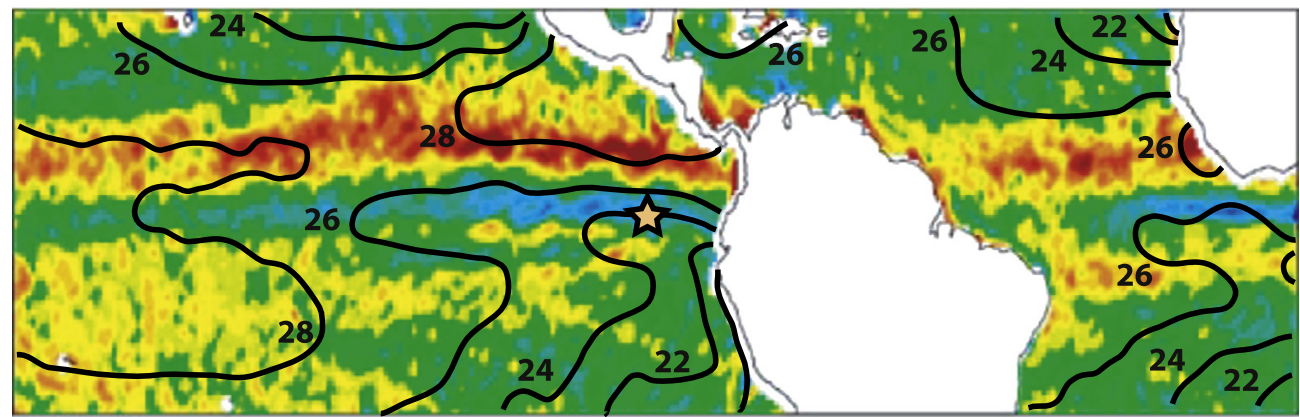

\section{June 2001}

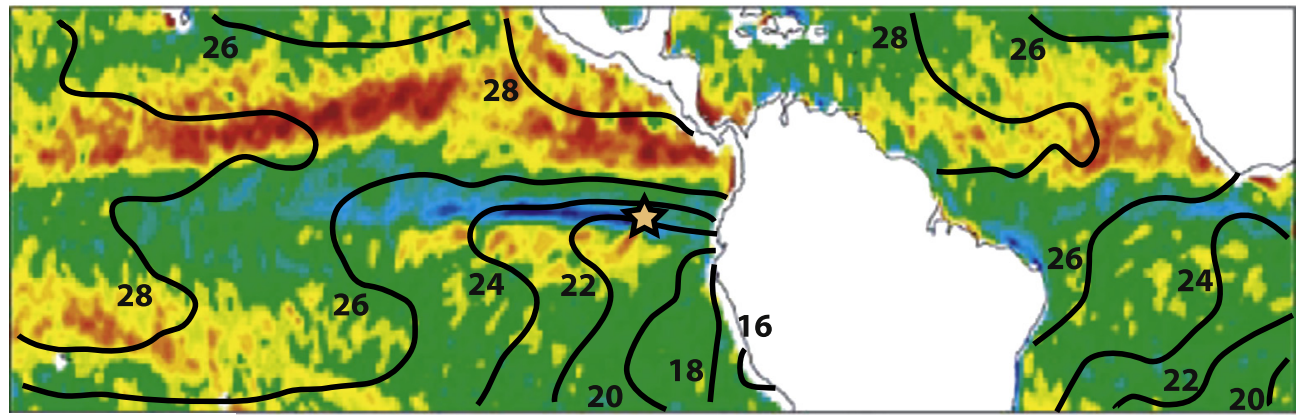

September 2001

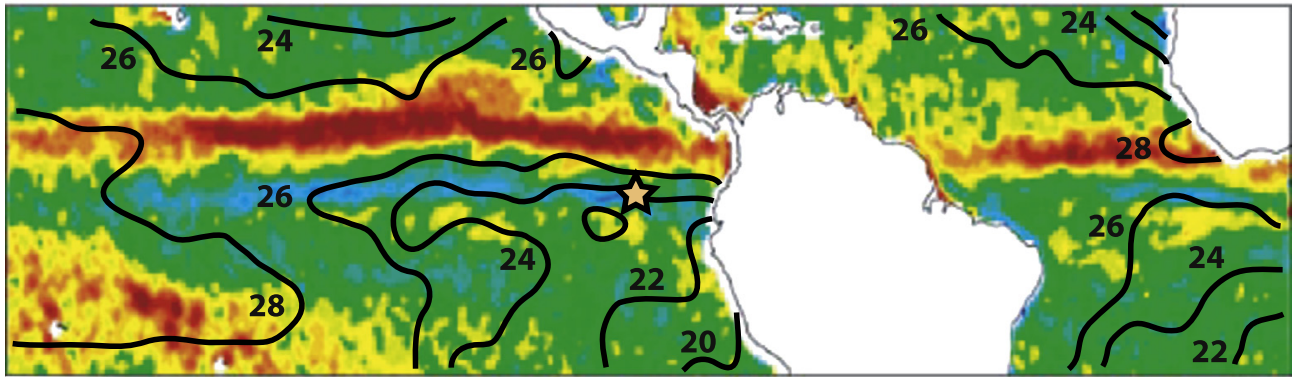

December 2001

Convergence $\left(10^{-5} / \mathrm{sec}\right)$

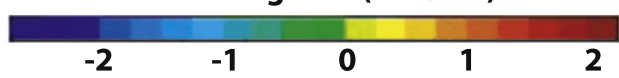

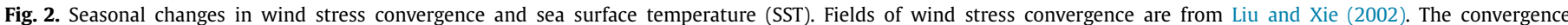

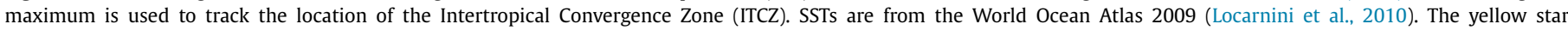

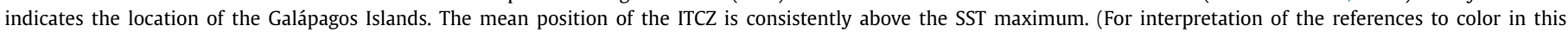
figure legend, the reader is referred to the web version of this article.)

In September 2004 we collected a $3.5 \mathrm{~m}$-long $9 \mathrm{~cm}$-diameter Nesje piston core (Conroy et al., 2008) and several water-mud interface cores from the lake (Sachs et al., 2009; Fig. 1c). Here we reconstruct El Niño variations during the Holocene from the concentration and hydrogen isotopic composition of a lipid biomarker from a single species of green algae and discuss the possible climate implications.

\section{Present-day climatology}

The pattern of precipitation in the eastern equatorial Pacific (EEP) depends on complex ocean-atmosphere interactions. The most prominent oceanic feature of the EEP is the latitudinal sea surface temperature (SST) gradient separating warm waters in the northeastern equatorial Pacific from cold water in the southeastern equatorial Pacific (the so-called "cold tongue") (Fig. 2). This 


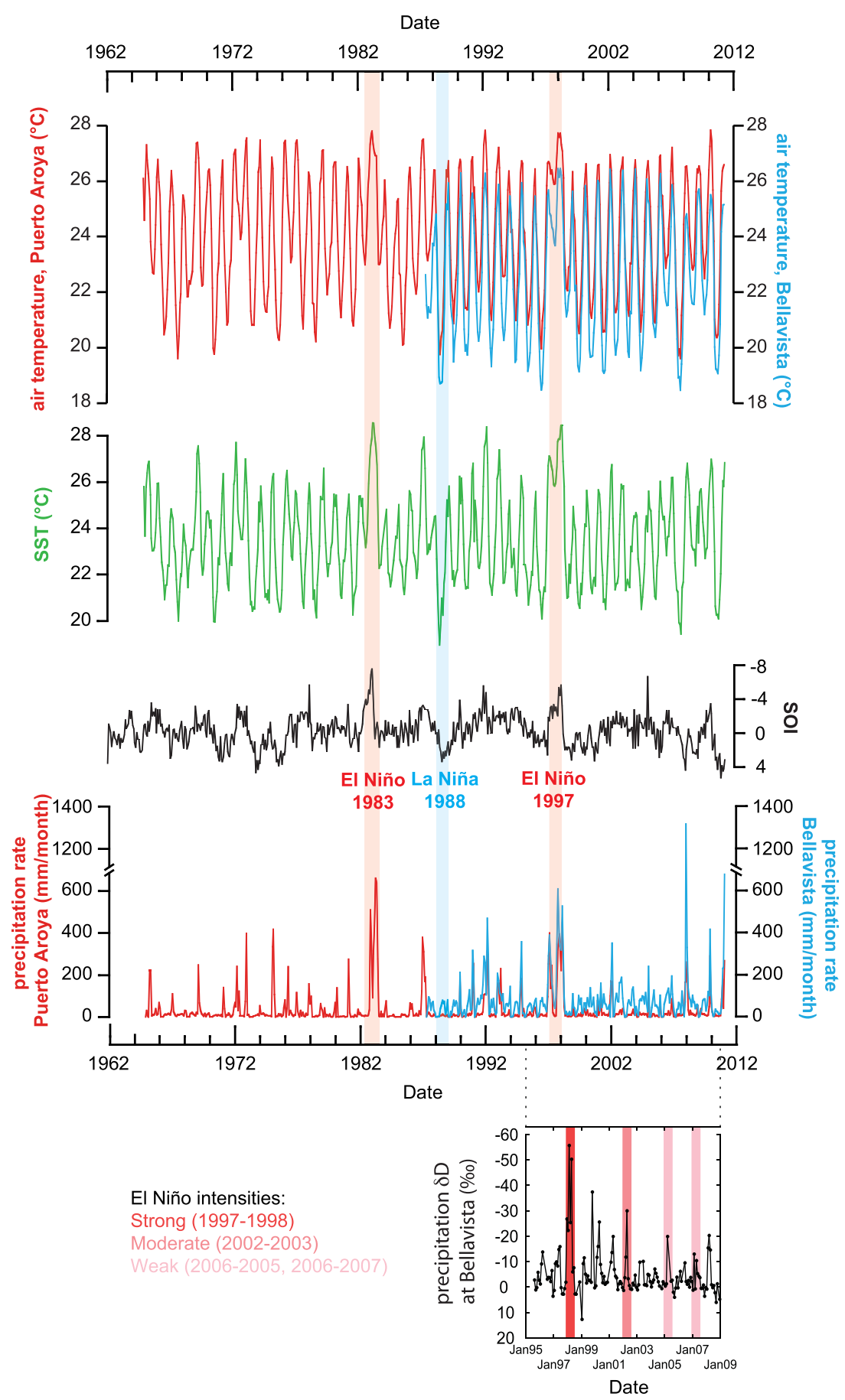

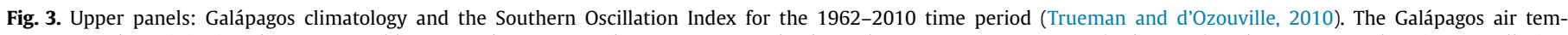

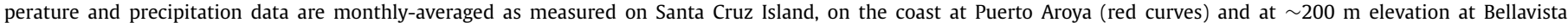

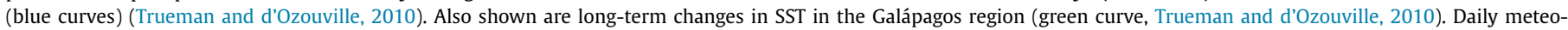

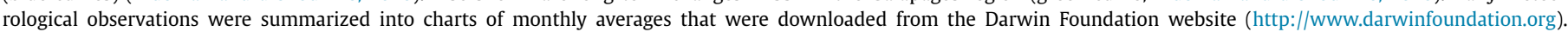

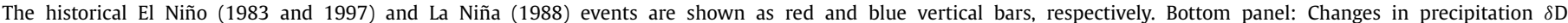

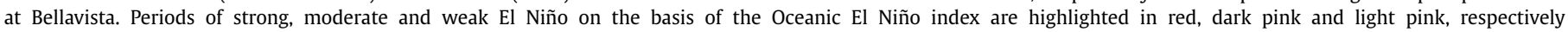
(http://ggweather.com/enso/oni.htm). (For interpretation of the references to color in this figure legend, the reader is referred to the web version of this article.)

SST gradient is sustained by the advection of cold water from the Peru margin by the Humboldt Current (Fig. 2). The changing direction of the Coriolis force at the equator reinforces the strength of the equatorial cold tongue because the associated equatorial divergence brings cold water to the surface (Kessler, 2006).

Because wind convergence occurs over SST maxima (Fig. 2), the seasonal and inter-annual changes in EEP SST fields ultimately shape the pattern of wind stress convergence there. These ocean- atmosphere interactions dictate the location of the ITCZ and its associated precipitation on seasonal and inter-annual timescales (Figs. 2, 3, 4). As the ITCZ location closely tracks the regional SST maxima (Fig. 2), the North-South SST gradient keeps the ITCZ North of the equator during most of the time. During austral summer the latitudinal SST gradient diminishes and the ITCZ migrates south toward the equator (Fig. 2). During non-El Niño years a double ITCZ straddling the equator is sometimes observed in austral 

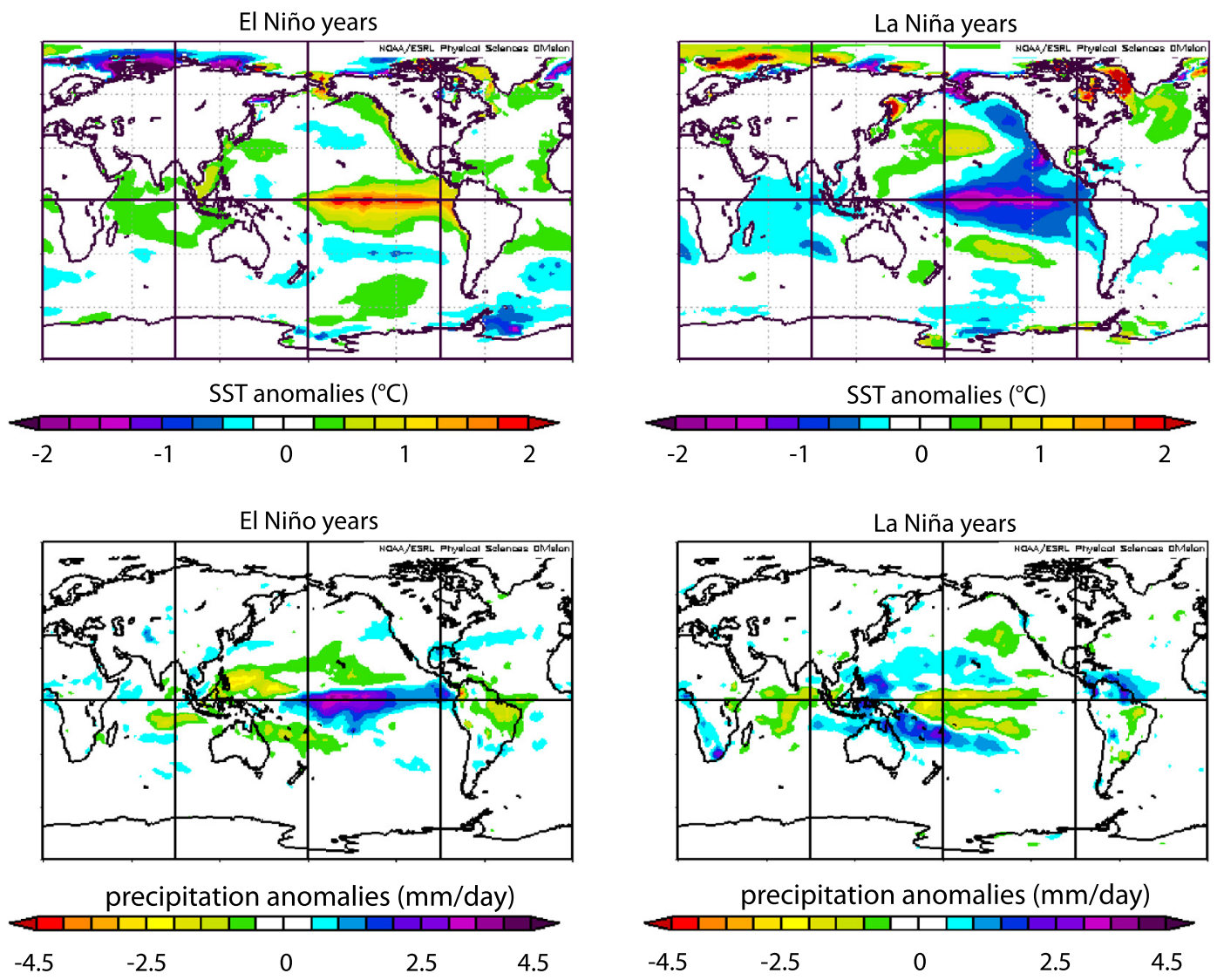

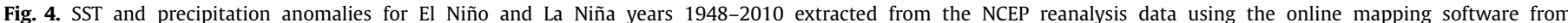

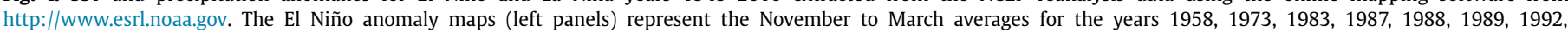
1998, 2003. The La Niña anomaly maps (right panels) represent the November to March averages for the years 1955, 1956, 1965, 1971, 1974, 1976, 1989, 1999, 2000.

summer (Liu and Xie, 2002; Gu et al., 2005; Fig. 2). During El Niño years, anomalously warm surface waters in the EEP cause a southward migration of the ITCZ, and heavy rains in the Galápagos Islands where precipitation can exceed the annual average by 10-fold (Figs. 3, 4).

El Niño rains have a pronounced impact on the hydrological budgets of small crater lakes in the Galápagos Islands such as El Junco Lake (Colinvaux, 1972; Atwood and Sachs, 2014). Lowelevation clouds prevent the lake from desiccation during the winter time, and a light drizzle, known locally as garúa, may contribute up to $25 \%$ of the water to the lake catchment annually (Pryet et al., 2012). As the lake is filled by rain falling within the narrow crater rim, its depth fluctuates slightly with the seasons. Inter-annually, the lake level fluctuates by $50 \%$ or more, rising with El Niño rains and falling during La Niña droughts (Colinvaux, 1972). Apart from a small overflow channel and possible seepage through the rim, the lake basin is closed, making it a natural rain gauge capturing past rainfall variability (Fig. 1c).

\section{Methods}

\subsection{Sample collection}

Water samples and sediment cores from El Junco Lake were collected in September 2004, during a dry period associated with a moderate La Niña event. Lake water $\delta \mathrm{D}$ values were analyzed at 1-m depth intervals with the method described in Zhang and Sachs (2007). Precision of water $\delta \mathrm{D}$ measurements was $0.5 \%(1 \sigma)$. The lake was $6 \mathrm{~m}$ deep and was well mixed at the time of the expedition, as evidenced by near-constant $\delta \mathrm{D}$ values $(7.3 \%$ at the surface and $7.6 \%$ at $5 \mathrm{~m})$, temperatures $\left(19.3^{\circ} \mathrm{C}\right.$ at $1 \mathrm{~m}, 18.6^{\circ} \mathrm{C}$ at
$5.5 \mathrm{~m})$ and oxygen concentrations $\left(93 \% \mathrm{O}_{2}\right.$ saturation at $1 \mathrm{~m}$ and $89 \% \mathrm{O}_{2}$ saturation at $5.5 \mathrm{~m}$ deep) in the water column. Though there is a slight trend of decreased temperature and $\mathrm{O}_{2}$ saturation in the water column, the bottom of the lake was well oxygenated. Sediments used in this study are from a sediment-water interface core (EJ7-MW1) recovered from the center of the lake, and from a nearby 3.5 -m-long core obtained with a 9-cm-diameter Nesje piston corer. The interface core was sampled every centimeter and the Nesje core was sampled every $5 \mathrm{~cm}$.

\subsection{Analyses of biomarkers in the sediment}

Sediment samples (about 0.8 to $1 \mathrm{~g}$ ) were freeze-dried prior to extraction with organic solvents. An internal standard containing $20 \mu \mathrm{g} C_{36} n$-alkane, $C_{21} n$-alkanol and $C_{21} n$-fatty acid was added to sediment samples prior to extraction. Lipid extractions were performed on a Dionex ASE-200 pressurized fluid extractor with dichloromethane (DCM) and methanol (MeOH) (9:1) at 1500 psi and $150^{\circ} \mathrm{C}$. Neutral lipids were separated from fatty acids on an aminopropyl cartridge-style SPE column (Burdick \& Jackson, size $500 \mathrm{mg} / 4 \mathrm{ml}$ ) by eluting with DCM/isopropyl alcohol (3:1). Neutral lipids were fractionated by column chromatography with $5 \%$ waterdeactivated silica gel. Hydrocarbons were eluted with hexane, and then further fractionated on activated silica gel to separate botryococcenes from other hydrocarbons by elution with hexane. Quantification of botryococcenes discussed in this paper is based on the comparison in gas chromatograms with an internal standard of $C_{36} n$-alkane using flame ionization detection. An Agilent 6890 gas chromatograph was operated with a programmable temperature vaporization injector (PTV), a $60 \mathrm{~m}$ Varian Chrompac CP-Sil 5 capillary column with $0.32 \mathrm{~mm}$ i.d. and $0.25 \mu \mathrm{m}$ film thickness, 
Table 1

${ }^{210} \mathrm{~Pb}$ activity, cumulative dry mass and modeled ages of El Junco Lake sediments. The modeled ages are based on the bulk density and ${ }^{210} \mathrm{~Pb}$ measurements. They are constrained by radiocarbon analyses of bulk sediment (INSTAAR, University of Colorado, Boulder, CO, USA), from which we infer deposition before (-) or during/after $(+/++)$ atmospheric nuclear bomb testing in the early 1960 's. dpm/g $=$ decays per minute per gram dry sediment.

\begin{tabular}{rccl}
\hline $\begin{array}{l}\text { Depth } \\
(\mathrm{cm})\end{array}$ & $\begin{array}{l}{ }^{210} \mathrm{~Pb} \text { activity } \\
(\mathrm{dpm} / \mathrm{g})\end{array}$ & $\begin{array}{l}\text { Cumulative dry mass } \\
\left(\mathrm{g} / \mathrm{cm}^{2}\right)\end{array}$ & $\begin{array}{l}\text { Modeled age } \\
(\mathrm{yr} \text { AD) }\end{array}$ \\
\hline 0.5 & 122.827 & 1.88 & 2001 \\
1.5 & 113.289 & 3.47 & 1996 \\
2.5 & 106.224 & 5.13 & 1991 \\
3.5 & 91.929 & 6.47 & 1986 \\
4.5 & 78.059 & 7.73 & $1982(++)$ \\
5.5 & 71.923 & 9.16 & 1977 \\
6.5 & 66.46 & 10.56 & 1972 \\
7.5 & 64.847 & 12.31 & $1964(++)$ \\
8.5 & 68.224 & 13.64 & $1957(+)$ \\
9.5 & 61.902 & 15.05 & 1947 \\
10.5 & 41.017 & 16.52 & $1936(-)$ \\
11.5 & 23.328 & 18.35 & 1924 \\
12.5 & 18.826 & 20.3 & 1910 \\
13.5 & 17.452 & 21.85 & 1897 \\
14.5 & 18.368 & 23.21 & 1877 \\
\hline
\end{tabular}

and helium as carrier gas. The temperature program was $80^{\circ} \mathrm{C}$ to $150^{\circ} \mathrm{C}$ at $10^{\circ} \mathrm{C} / \mathrm{min}$, then to $325^{\circ} \mathrm{C}$ at $4{ }^{\circ} \mathrm{C} / \mathrm{min}$, and a $13 \mathrm{~min}$ isothermal period.

\subsection{Hydrogen isotope analyses of lipid biomarkers}

The hydrogen isotopic composition of botryococcenes was measured by gas chromatography-isotope ratio-mass spectrometry (GC-IRMS) with a Thermo Delta V mass spectrometer, equipped with a Trace Ultra GC and a GC-C III pyrolysis furnace.

The Trace GC was equipped with a PTV inlet operated in splitless mode, a $30 \mathrm{~m}$ DB-5 capillary column (J\&W Scientific) with $0.25 \mathrm{~mm}$ i.d. and $0.25 \mu \mathrm{m}$ film, and was operated at a constant helium flow rate of $1 \mathrm{ml} / \mathrm{min}$. The oven temperature started at $80^{\circ} \mathrm{C}$, rose to $200^{\circ} \mathrm{C}$ at $10^{\circ} \mathrm{C} / \mathrm{min}$, then to $325^{\circ} \mathrm{C}$ at $5.5^{\circ} \mathrm{C} / \mathrm{min}$, followed by $12 \mathrm{~min}$ at $325^{\circ} \mathrm{C}$. Effluent from the GC was pyrolyzed in a graphite-lined ceramic tube at $1400^{\circ} \mathrm{C}$. The hydrogen gas stream was introduced to the mass spectrometer via an open split, where a flow of helium carried the $\mathrm{H}_{2}$ gas into the mass spectrometer.

To every sample was added a set of co-injection standards (androstane, $C_{26}$ and $C_{32} n$-alkanes) with known $\delta \mathrm{D}$ values that were chosen to bracket the peaks of interest in the chromatograms. All isotopic standards were obtained from Dr. Arndt Schimmelmann at the Biogeochemical Laboratory, Indiana University. Each sample was run in triplicate and the standard deviation was usually less than $5 \%$. A set of $15 n$-alkanes with known $\delta \mathrm{D}$ values (Mixture A or B) acquired from Indiana University were injected every 6 to 9 runs to ensure the accuracy of our data. Reported data are based on the first eluting $C_{34}$ botryococcene (Zhang et al., 2007) and the $\delta \mathrm{D}$ values are reported with reference to the VSMOW standard.

\subsection{Dating and age models}

The sediment samples used in this paper were taken from two sediment cores, one $75 \mathrm{~cm}$-long water-mud (WM) interface core, EJ7-MW1 and one $372 \mathrm{~cm}$-long Nesje core. Because the upper part of the Nesje core was lost, we analyzed sediments from both cores and present results from the composite sedimentary sequence.

The upper part of the interface core $(0-15 \mathrm{~cm})$ was dated with ${ }^{210} \mathrm{~Pb}$ (Table 1). ${ }^{210} \mathrm{~Pb}(46.5 \mathrm{keV})$ and ${ }^{214} \mathrm{~Pb}$ (295 and $352 \mathrm{keV}$ ) were measured on dried sediments on a low-energy germanium detector (Canberra Instruments). Counter efficiency was calibrated with sequential additions of known amounts of standard pitchblend. Unsupported ${ }^{210} \mathrm{~Pb}$ was calculated by subtracting supported ${ }^{210} \mathrm{~Pb}$, which is in equilibrium with ${ }^{214} \mathrm{~Pb}$, from total ${ }^{210} \mathrm{~Pb} . \mathrm{A}{ }^{210} \mathrm{~Pb}$ chronology was constructed assuming constant rate of supply (CRS) and by relating the exponential ${ }^{210} \mathrm{~Pb}$ decay profiles with the cumulative dry mass - depth profiles as determined using bulk

Table 2

Radiocarbon ages of El Junco Lake sediments.

\begin{tabular}{|c|c|c|c|c|c|c|c|c|}
\hline $\begin{array}{l}\text { Depth } \\
(\mathrm{cm})^{\mathrm{a}}\end{array}$ & Core $^{b}$ & $\mathrm{Lab}^{\mathrm{c}}$ & $\begin{array}{l}{ }^{14} \mathrm{C} \text { age } \\
(\mathrm{yr} B P)^{\mathrm{d}}\end{array}$ & $\begin{array}{l}\text { Std. dev. } \\
( \pm)\end{array}$ & $\begin{array}{l}\delta^{13} \mathrm{C} \\
(\% 0)\end{array}$ & $\begin{array}{l}\text { Modern } \\
\text { fraction }\end{array}$ & $\begin{array}{l}\text { Cal. age } \\
(\text { yr A.D. })^{\mathrm{e}}\end{array}$ & $\begin{array}{l}\text { Modeled age } \\
(\mathrm{yr} \mathrm{BP})^{\mathrm{f}}\end{array}$ \\
\hline 10.5 & WM & IN & 75 & 25 & -27.5 & $0.9906 \pm 0.0027$ & 1706-1932 & 14 \\
\hline 30.5 & WM & IN & 250 & 25 & -23.8 & $0.9695 \pm 0.0028$ & $1642-1800$ & 184 \\
\hline 50.5 & WM & IN & 400 & 25 & -27.2 & $0.9514 \pm 0.0024$ & $1456-1626$ & 363 \\
\hline 64.0 & $\mathrm{~N}$ & AA & 455 & 38 & -28.8 & $0.9450 \pm 0.0045$ & $1421-1622$ & 466 \\
\hline 70.5 & WM & IN & 450 & 25 & -26.2 & $0.9454 \pm 0.0027$ & $1440-1613$ & 492 \\
\hline 84.0 & $\mathrm{~N}$ & AA & 707 & 43 & -27.9 & $0.9157 \pm 0.0049$ & $1278-1394$ & 624 \\
\hline 104.0 & $\mathrm{~N}$ & AA & 1171 & 40 & -26.3 & $0.8643 \pm 0.0043$ & $782-1016$ & 979 \\
\hline 124.0 & $\mathrm{~N}$ & AA & 1235 & 42 & -26.5 & $0.8575 \pm 0.0042$ & $715-976$ & 1144 \\
\hline 142.0 & $\mathrm{~N}$ & AA & 1420 & 40 & -27.7 & $0.8379 \pm 0.0041$ & $600-770$ & 1321 \\
\hline 164.0 & $\mathrm{~N}$ & AA & 1885 & 40 & -25.4 & $0.7908 \pm 0.0039$ & $77-323$ & 1783 \\
\hline 184.0 & $\mathrm{~N}$ & AA & 2283 & 42 & -21.6 & $0.7526 \pm 0.0039$ & $-392 \sim-195$ & 2244 \\
\hline 204.0 & $\mathrm{~N}$ & AA & 2729 & 38 & -26.8 & $0.7120 \pm 0.0034$ & $-910 \sim-790$ & 2729 \\
\hline 224.0 & $\mathrm{~N}$ & AA & 2820 & 42 & -20.5 & $0.7040 \pm 0.0037$ & $-1012 \sim-790$ & 2975 \\
\hline 230.0 & $\mathrm{~N}$ & AA & 2949 & 55 & -22.7 & $0.6927 \pm 0.0048$ & $-1263 \sim-912$ & 3105 \\
\hline 250.0 & $\mathrm{~N}$ & AA & 3652 & 50 & -30.8 & $0.6347 \pm 0.0039$ & $-2133 \sim-1771$ & 3840 \\
\hline 270.0 & $\mathrm{~N}$ & AA & 3855 & 46 & -29.2 & $0.6166 \pm 0.0035$ & $-2457 \sim-2045$ & 4287 \\
\hline 290.0 & $\mathrm{~N}$ & AA & 4679 & 47 & -29.4 & $0.5585 \pm 0.0032$ & $-3627 \sim-3112$ & 5324 \\
\hline 310.0 & $\mathrm{~N}$ & AA & 5674 & 55 & -30.1 & $0.4935 \pm 0.0034$ & $-4583 \sim-4340$ & 6398 \\
\hline 330.0 & $\mathrm{~N}$ & AA & 6491 & 45 & -29.5 & $0.4457 \pm 0.0025$ & $-5479 \sim-5318$ & 7349 \\
\hline 350.0 & $\mathrm{~N}$ & AA & 7564 & 47 & -22.7 & $0.3900 \pm 0.0023$ & $-6453 \sim-6253$ & 8292 \\
\hline 370.0 & $\mathrm{~N}$ & AA & 8162 & 49 & -31.9 & $0.8162 \pm 0.0022$ & $-7310 \sim-6842$ & 9029 \\
\hline
\end{tabular}

a A composite core depth was adopted for both cores.

b $\mathrm{N}=$ Nesje piston core, WM = EJ7-MW1 water-mud interface core.

c $\mathrm{AA}=$ Arizona AMS Laboratory, Tucson, AZ, USA; IN = INSTAAR, University of Colorado, Boulder, CO, USA.

d ${ }^{14} \mathrm{C}$ ages of bulk organic material.

e Calibrated age ranges $(2 \sigma)$ using the Southern Hemisphere 2004 calibration curve.

f Modeled ages $(2 \sigma)$ were constructed using OxCal 4.0 .1 beta, with the $P_{-}$sequence model and $k=0.5 \mathrm{~cm}^{-1}$. Shown are the mid points of the modeled $2 \sigma$ age range. Sediment ages were linearly interpolated between dated intervals. 


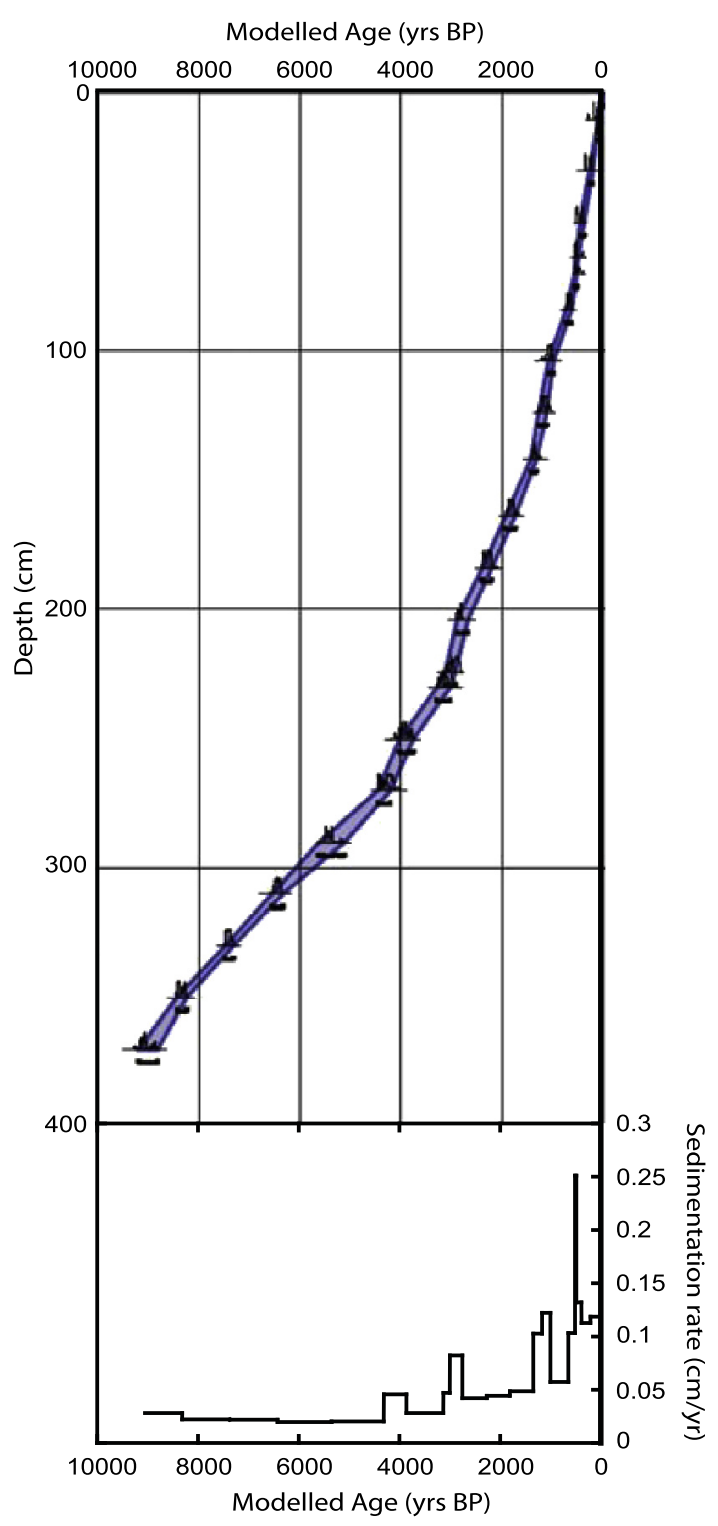

Fig. 5. Age-depth relationship of the El Junco Lake composite sedimentary sequence constructed using OxCal 4.0.1 beta software (Bronk Ramsey, 2008), adopting the Northern Hemisphere 2009 calibration curve and the $P_{-}$sequence model with $k=1 \mathrm{~cm}^{-1}$. The agreement indices of individual dates are indicated next to the sample names (top panel). Also shown are the computed sedimentation rates (bottom panel).

density measurements and using a CRS computer model (Appleby and Oldfield, 1978). ${ }^{210} \mathrm{~Pb}$ does not provide direct dates sensus stricto. But if it is assumed that the core top is of modern age and a CRS occurred over the time window covered by the sedimentary sequence, then an age model can be derived from the unsupported ${ }^{210} \mathrm{~Pb}$ calculation.

We selected 17 samples from the Nesje core and four samples $(10.5,30.5,50.55$ and $70.5 \mathrm{~cm}$ intervals) from the WM core for radiocarbon dating (Table 2). A total of 21 sediment samples were dated at the Arizona AMS Laboratory, Tucson, AZ, USA and INSTAAR, University of Colorado, Boulder, CO, USA (Table 2, Fig. 5). We consider any reservoir effect that might influence the radiocarbon ages unlikely since: (i) there are no carbonate rocks in the small volcanic crater in which the lake sits, (ii) the lake is shallow $(6 \mathrm{~m})$ and well mixed, and (iii) the lake is unlikely to receive carbonate from sea spray since it is at $670 \mathrm{~m}$ above sea level, under a stable atmospheric inversion much of the year, and close to the equator where storms are rare. Age uncertainties range from a few years to decades at the top of the core, which is based on ${ }^{210} \mathrm{~Pb}$ dating, to a few decades to centuries at the bottom of the core, which is based on radiocarbon dating (Tables 1, 2).

Radiocarbon measurements indicate the presence of nuclearbomb-test-derived ${ }^{14} \mathrm{C}$ at core top, assumed to correspond to the early 1960s (Table 1). Overlapping radiocarbon dates were then used to connect the WM and the Nesje cores and build a composite sedimentary sequence. This was achieved by connecting the 64- $\mathrm{cm}$ interval in the Nesje core to the $70-\mathrm{cm}$ interval in the WM core, which gave the same radiocarbon ages within dating uncertainties (Table 2), suggesting that the composite sedimentary sequence provides a continuous record of sediment accumulation.

To build the composite age model, we then used the OxCal 4.0.1 beta software (Bronk Ramsey, 2008) that incorporates both CRS modeled ${ }^{210} \mathrm{~Pb}$ ages and radiocarbon dates of bulk sediment from the WM core and the Nesje core (Tables 1, 2; Fig. 5). Radiocarbon dates were calibrated using the Southern Hemisphere 2004 calibration curve (McCormac et al., 2004). The model used a P_sequence model with $k=0.5 \mathrm{~cm}^{-1}$. Sediment ages between dated samples were linearly interpolated. The final age model was then based on a mixture of ${ }^{210} \mathrm{~Pb}$ ages and radiocarbon dates fort the first $70 \mathrm{~cm}$ of the composite sedimentary sequence, and on radiocarbon dates alone for deeper sediment depths (Fig. 5). Sedimentation rates varied from $\sim 0.02$ to $\sim 0.2 \mathrm{~cm} / \mathrm{yr}$ from early to late Holocene, so that one sample (1 cm thick) integrates 50 to 5 year of precipitation in average (Fig. 5). The apparent change in sedimentation rate is likely due to compaction, which squeezes adjacent sediment layers more closely together, expelling water at greater depth. We subsampled at $5 \mathrm{~cm}$ intervals in the early and mid-Holocene, resulting in a time resolution of 200 to 250 years for that period.

\section{Results and discussions}

\subsection{Precipitation anomalies inferred from biomarkers and compound-specific $\delta D$ values}

\subsubsection{Botryococcus braunii (B race) ecology and botryococcenes as recorders of tropical heavy rains}

El Junco sediments contain a suite of lipid biomarkers that can be traced back to specific organisms (Zhang et al., 2007, 2011, $2013,2014)$. The occurrence of alkadienes, botryococcenes and lycopadienes in the water column and surface sediments indicate the co-existence of all three races (A, B and $\mathrm{L}$ ) of the green alga Botryococcus braunii (Zhang et al., 2007). But alkadienes (from the $A$ race) occur in only the trace amounts in the surface sediment and water column, and lycopadienes (from the $\mathrm{L}$ race) appear in the sediments deposited since only 460 years ago. In contrast, botryococcenes, highly branched isoprenoid hydrocarbons unique to the B race (Aaronson et al., 1983; Metzger et al., 1985), are present throughout the Holocene, indicating a predominance of the $\mathrm{B}$ race. The concentrations of botryococcenes varied by 5 orders of magnitude, from $<1$ to $16,700 \mu \mathrm{g} / \mathrm{g}$, through the Holocene (Fig. 6a; data are provided in the supplementary table), implying temporal changes in the environmental conditions most favorable to $\mathrm{B}$. braunii $\mathrm{B}$ race.

B. braunii occurs most frequently in oligotrophic lakes at temperate and tropical latitudes (Aaronson et al., 1983; Belcher, 1968; Kebede and Belay, 1994; Richerson et al., 1986; Townsend, 2001; Wake and Hillen, 1980). The causes of B. braunii blooms are not well understood, particularly when different races are concerned, since most ecological studies have not differentiated between the $\mathrm{A}, \mathrm{B}$ and $\mathrm{L}$ races. One general consensus is that the $\mathrm{B}$ race $\mathrm{B}$. braunii blooms often occur after heavy rain events. One example is given in Wake and Hillen (1980) who documented the bloom of $B$ race $B$. braunii in the Darwin River Reservoir (DDR, Australia) in 1976-1977, and suggested that lakes with a poorly developed 
Age (yr BP)

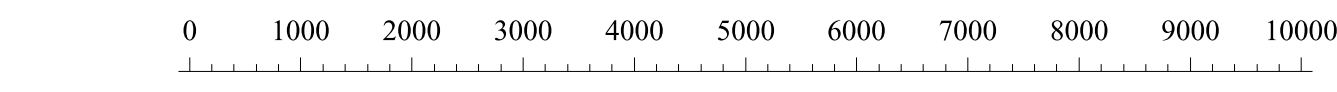
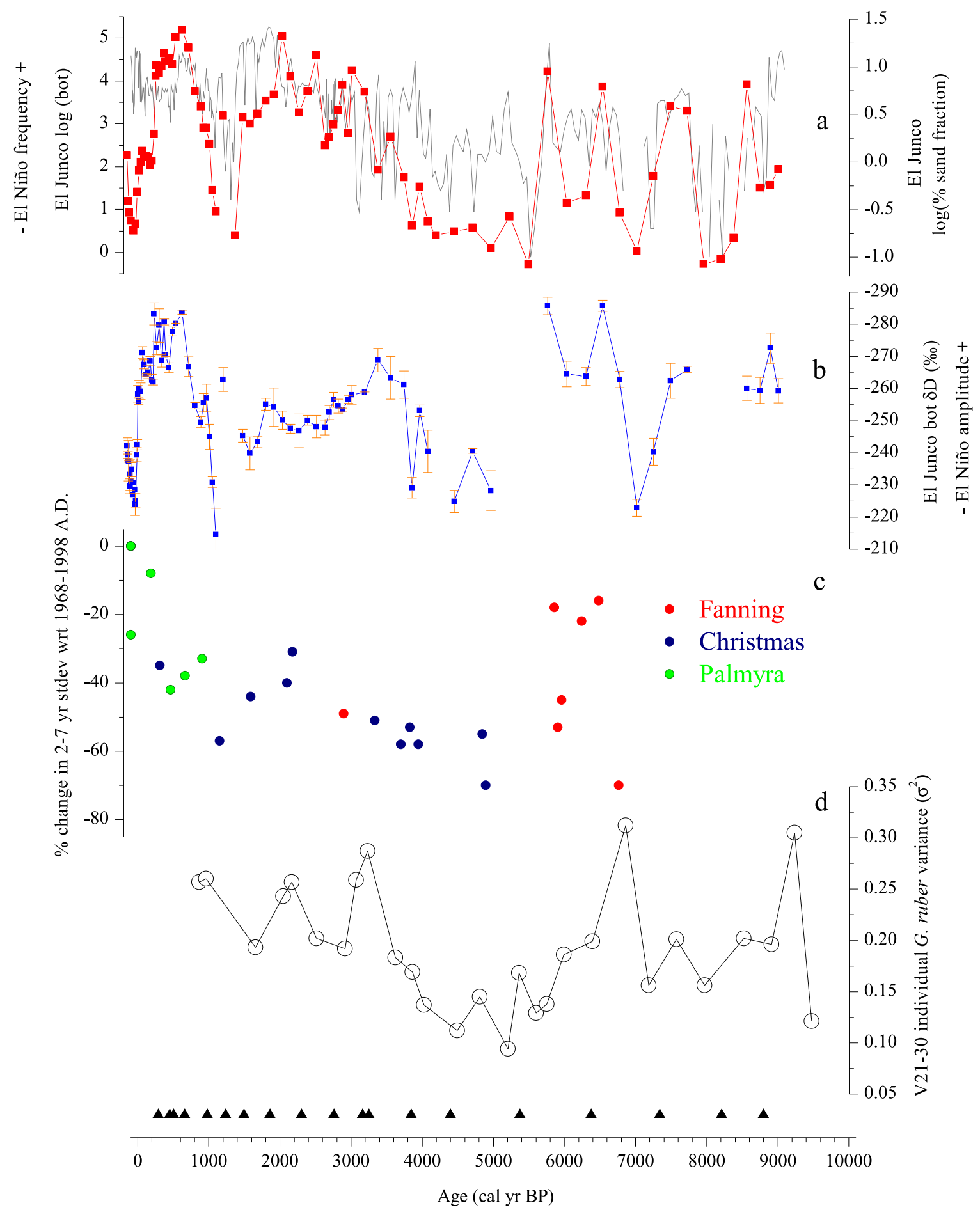

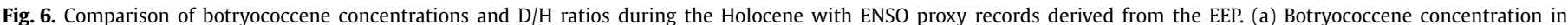

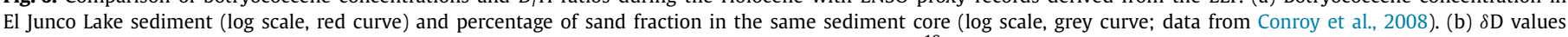

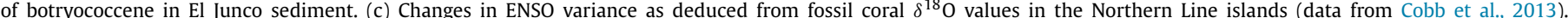

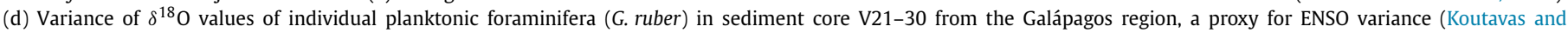
Joanides, 2012). (For interpretation of the references to color in this figure legend, the reader is referred to the web version of this article.)

littoral margin, and without fish (large-particle grazers) are more likely to support B. braunii blooms. The DDR is a stratified lake, having an average depth of $6 \mathrm{~m}$ (maximum depth of $25 \mathrm{~m}$ ). In December 1974 , shortly prior to the appearance of the bloom, heavy rains associated with a cyclone caused the reservoir to overflow, resulting in the disappearance of mullet and barramundi. Following the cyclone the algal numbers gradually rose in the reservoir for the next 20 months (Wake and Hillen, 1980). Another example 


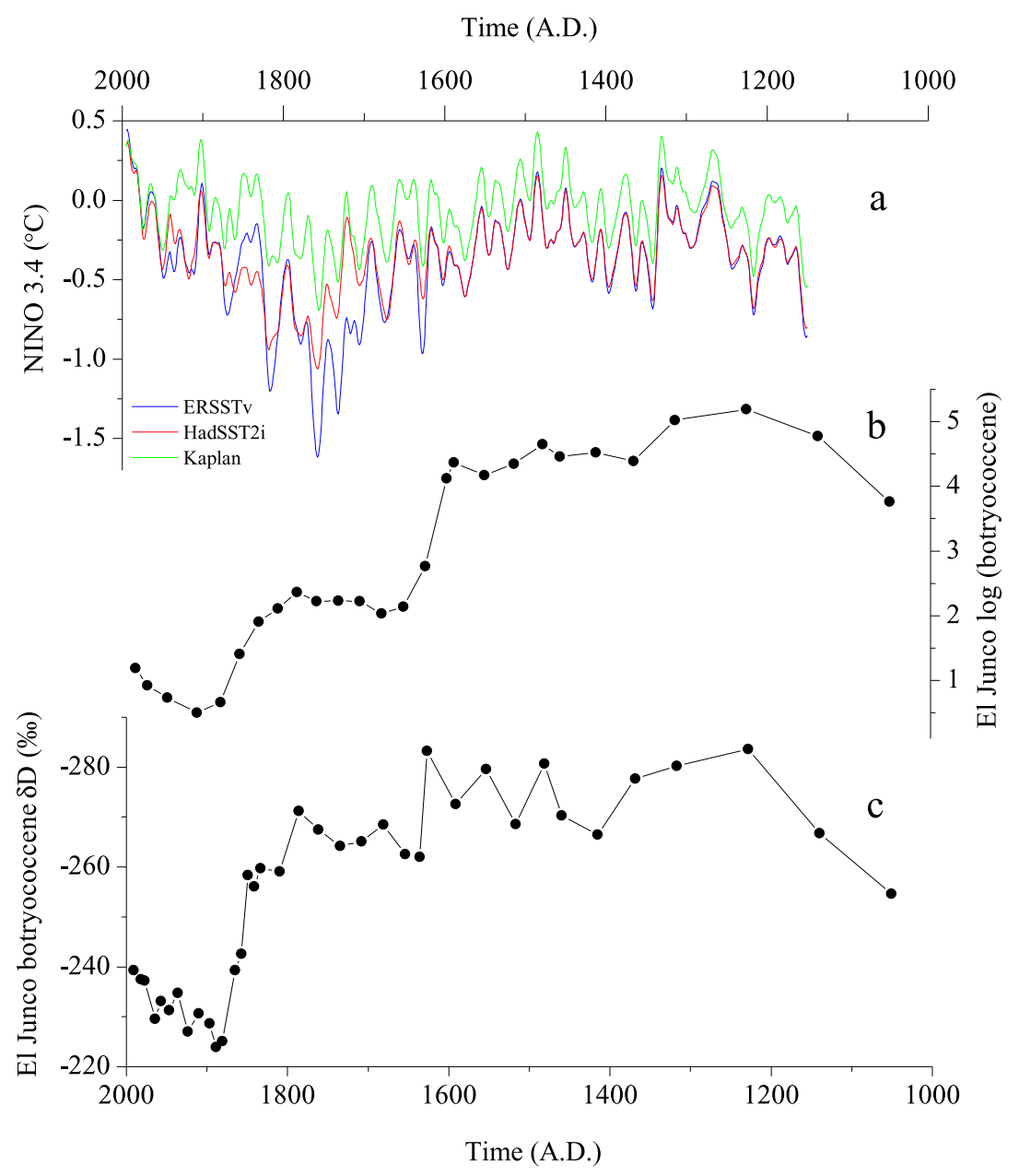

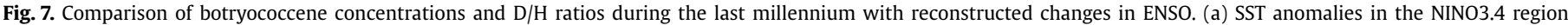

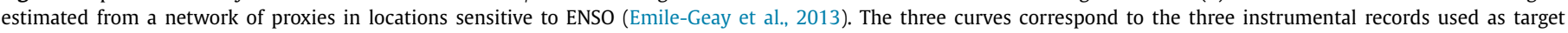
datasets for computing the NINO3.4 index. (b) Botryococcene concentrations in El Junco sediment (log scale). (c) $\delta \mathrm{D}$ values of botryococcenes in El Junco sediment.

is Debundsha Lake, a small crater lake in tropical West Cameroon. The lake has low conductivity and poor littoral developments owing to the very high annual rainfall of $10 \mathrm{~m}$. While desmids and diatoms were commonly observed near the shoreline, B. braunii dominated the phytoplankton assemblage of the lake, most likely due to the muted influence of the shoreline area (Green et al., 1974).

El Junco resembles the DDR and Debundsha Lake in many respects. All three lakes have steeply sloping catchments, small surface areas, shallow water depths and narrow littoral zones (Fig. 1c). Heavy rains in lakes such as the DDR, Debundsha Lake and El Junco cause water to spill out over the rim of the catchment, flushing out nutrients and grazers. These conditions appear to be favorable for the blooming of $B$. braunii. Heavy rains in the Galápagos likely cause nutrient concentrations to drop in El Junco as the lake water is diluted by rainwater, the lake level reaches the height of the overflow channel (Conroy et al., 2008), the littoral margin shrinks, and grazing pressure diminishes. A likely contributor to the diminution of nutrients in El Junco Lake during El Niño events is the decline in guano deposition in the catchment as seabird populations plummet (Steinitz-Kannan et al., 1998). Taken together, these changes in El Junco Lake during El Niño events are expected to favor blooms of $B$. braunii. Very low concentrations of botryococcenes were detected in suspended particulate matter collected in 2004 (Zhang et al., 2007), a non-El Niño year, indicating that $B$. braunii does not bloom during dry periods such as those asso- ciated with La Niña events, the dry season and/or with the garúa season.

We measured the hydrogen isotope ratios of the $C_{34}$ botryococcene isomer that eluted first (Zhang et al., 2007) in order to be consistent down-core (Standard deviation < 5\%). Data are provided in supplementary table. Hydrogen isotope ratios of water in a closed basin, like El Junco, are dictated by the relative rates of precipitation and evaporation, and the isotopic composition of precipitation, the latter of which is strongly associated with rainfall rates in the tropics (Dansgaard, 1964; Kurita et al., 2009; Risi et al., 2008). Using a model of the isotope hydrology of El Junco Lake Atwood and Sachs (2014) showed that the lake water $\delta$ D was primarily controlled by rainfall rates during El Niño episodes, as opposed to evaporation or water loss through seepage or overflow. Since hydrogen isotope ratios $(\mathrm{D} / \mathrm{H})$ in botryococcenes track water $\delta \mathrm{D}$ values with near perfection, with an offset due to isotope fractionation during lipid biosynthesis (Zhang and Sachs, 2007; Zhang et al., 2009), changes in rainfall amount are imprinted in the isotopic composition of botryococcenes, with negative (positive) $\delta \mathrm{D}$ values co-occurring with wetter (drier) periods.

\subsubsection{Proof of concept: botryococcene concentrations and $\delta D$ values during the last millennium}

In Fig. 7 we compare the botryococcene concentrations and $\delta \mathrm{D}$ values (Figs. $7 \mathrm{~b}, \mathrm{c}$ ) in El Junco Lake to SST anomalies in the NINO3.4 region of the EEP reconstructed from climate proxy records with annual resolution, such as corals, tree rings and ice 
cores (Fig. 7a) (Emile-Geay et al., 2013). Increasing NINO3.4 SST anomalies $1100-1300 \mathrm{AD}$, followed by a plateau from 1300 to $1600 \mathrm{AD}$, and a sharp decrease 1600-1800 AD, are observed in the botryococcene concentration and $\delta \mathrm{D}$ records. The last two centuries diverge in the two data sets, as the NINO3.4 reconstruction suggests a sharp increase in SST from 1800 to 2000 AD, while the botryococcene records from El Junco imply only a moderate increase in El Niño occurrences over the last century, and no indication of the very high ENSO variance implied by the most recent values of the coral-based NINO 3.4 record (Fig. 7; Cobb et al., 2013).

Two factors can be invoked to explain such a mismatch between the El Junco record and the NINO3.4 SST reconstruction from Emile-Geay et al. (2013) over the last century. First, it is worth mentioning at this stage that a distinction should be made between the eastern Pacific El Niño events and the central Pacific El Niño events. While the SST reconstruction of Emile-Geay et al. (2013) would be sensitive to both types of El Niño events, the precipitation anomalies at El Junco, which is situated farther east, would be muted when central Pacific El Niño occurs (Ashok et al., 2007). A recent attempt to reconstruct central Pacific El Niño events using monthly SST datasets back to 1880 AD suggests that the probability that a given year was a central Pacific El Niño year has increased over the past century (Pascolini-Campbell et al., 2014). Such a result may at least partly explain why ENSO appears more dominant in the central equatorial Pacific than in the eastern equatorial Pacific over the second half of the twentieth century. Secondly, changes in the mean state of the Pacific over the last $\sim 250$ years could have modified the El Niño teleconnection to El Junco in a way that is difficult to assess. Modeldata comparisons suggest that the spatial teleconnection pattern of climatic anomalies associated with El Niño events can change when different climatic backgrounds occur in response to changes in orbital geometry and the flux of freshwater to the North Atlantic from remnant ice sheets (Braconnot et al., 2012). Whether or not climatic forcings over the last millennium modified the ENSO teleconnection patterns, the above-mentioned factors warrant caution when interpreting relationships between proxy records on the basis of relationships established between those proxies and the modern climate (Braconnot et al., 2012).

\subsubsection{Temporal changes in botryococcene concentrations and their $\mathrm{D} / \mathrm{H}$ signature over the Holocene}

Based on the ecological niche likely occupied by Botryococcus braunii, Atwood and Sachs (2014) propose that botryococcene $\delta \mathrm{D}$ values reflect the lake $\delta \mathrm{D}$ values inherited from the $\delta \mathrm{D}$ of rainfall during El Niño events. Oligotrophic conditions suitable to B. braunii blooms being observed only during moderate to strong El Niño events in El Junco Lake, large shifts in the sedimentary concentration of botryococcenes may result from changes in the occurrence of moderate to strong El Niño events. Under such circumstances, our record differs from other proxy reconstructions of ENSO that integrate both El Niño and La Niña events (e.g. Leduc et al., 2009a; Koutavas and Joanides, 2012; Emile-Geay et al., 2013). The association of $B$. braunii blooms with El Niño conditions hence makes botryococcenes an excellent biomarker for sampling the warm phases of ENSO. In addition, it is expected that $\delta \mathrm{D}$ values of botryococcene will decline when precipitation rates increase, possibly providing a metric for the severity of extreme rainfall events that are associated with El Niño events (Atwood and Sachs, 2014). This hypothesis is corroborated by the 13 -year-long monthly $\delta \mathrm{D}$ record of precipitation from Bellavista (Fig. 3). During strong El Niño events such as the 1997-1998 El Niño, precipitation $\delta \mathrm{D}$ decreased by up to $60 \%$, while during moderate (as in 2002-2003) and weak (as in 2004-2005 and 2006-2007) El Niños precipitation $\delta \mathrm{D}$ decreased by only $\sim 30 \%$ and $\sim 10-20 \%$, respectively (Fig. 3 ).
Botryococcene concentrations spanned five orders of magnitude during the Holocene (Fig. $8 \mathrm{a}$ ), while botryococcene $\delta \mathrm{D}$ values varied from -286 to $-214 \%$ (Fig. 8b). Interestingly, low botryococcene $\delta \mathrm{D}$ values coincided with high botryococcene concentrations (Fig. 8a, b). If El Niño rains are the exclusive driver of the El Junco Lake trophic alterations favorable to B. braunii blooms, we anticipate that changes in El Niño frequency will be recorded by sedimentary concentrations of botryococcenes, which will increase when occurrences of El Niño events increase. Conversely, since the $\delta \mathrm{D}$ values of botryococcene capture the $\delta \mathrm{D}$ values of rainfall occurring during El Niño events (Fig. 3; Atwood and Sachs, 2014), we attribute changes in botryococcene $\delta \mathrm{D}$ values to changes in the severity of El Niño events. By extension, we propose that by pairing the concentration of botryococcenes with their $\mathrm{D} / \mathrm{H}$ composition, two strictly independent parameters, it is possible to qualitatively reconstruct both the frequency (concentration) and severity $(\delta \mathrm{D}$ values) of El Niño events during the Holocene. We hence interpret the coincidence of low botryococcene $\delta \mathrm{D}$ values (which we attribute to periods of increased intensity of El Niño events) with high botryococcene concentrations (which we attribute to periods of increased frequency of El Niño events) as indicating a tight coupling between the frequency and the amplitude of El Niño wet periods during the Holocene (Fig. 8a, b).

High-amplitude fluctuations of botryococcene concentrations and $\delta \mathrm{D}$ values characterize the period from 9200 to $5600 \mathrm{yr} \mathrm{BP}$, implying large fluctuations in El Niño occurrences at the multicentennial time scale during the early Holocene (Fig. 8a, b). The mid-Holocene (5600 to $3500 \mathrm{yr} \mathrm{BP}$ ) is characterized by low concentrations and high $\delta \mathrm{D}$ values of botryococcenes, implying a prolonged period of substantially reduced precipitation that we attribute to infrequent and weak El Niño events (Fig. 8a, b). From 5600 to 5200 yr BP and from 4400 to 4200 yr BP the botryococcene concentrations were so low that isotope measurements could not be made, signaling very infrequent El Niño events. A transition to high concentrations and low $\delta \mathrm{D}$ values of botryococcenes 4000-3500 yr BP implies high rainfall rates and lake levels that indicate the re-emergence of strong and frequent El Niños. Such conditions persisted until $\sim 2000 \mathrm{yr} \mathrm{BP}$, after which substantial drying and weak El Niños are inferred from a hundred-fold drop in botryococcene concentrations over the next 500 years and the highest $\delta \mathrm{D}$ values of the entire record $\sim 1200 \mathrm{yr} \mathrm{BP}$ (Fig. $8 \mathrm{a}, \mathrm{b}$ ). The subsequent return of strong and frequent El Niño events 1000-600 yr BP is supported by a large increase in the concentration and decrease in the $\delta \mathrm{D}$ value of botryococcenes. Such conditions persisted until $\sim 200$ yr BP $(\sim 1750$ A.D.) when a transition to arid conditions occurred that lasted until the latter half of the 20th century (Sachs et al., 2009).

Conroy et al. (2008) interpreted grain size changes of El Junco sediments in terms of rainfall variations associated with both the mean climate state and ENSO. Changes in the coarse (sand) fraction of sediment, thought to be sensitive to strong erosion events caused by heavy precipitation during El Niño events, fluctuate synchronously with botryococcene concentrations (Fig. 6a), and to a lesser extent with botryococcene $\delta \mathrm{D}$ values (Fig. 6b). Such similar patterns of change between the sand fraction of sediment, its botryococcene concentrations, and their $\delta \mathrm{D}$ values, lend support to the notion that they all result from the same forcing. We propose the most parsimonious forcing is heavy rains associated with strong and/or frequent El Niño events. This further suggests that periods of frequent El Niño events coincided with periods of strong El Niño events (Fig. 6a, b).

Ideally, ENSO reconstructions would be based on archives with sub-annual resolution from locations where the inter-annual variability of hydrology is highly and predominantly sensitive to ENSO. Coral $\delta^{18} \mathrm{O}$ records from the central tropical Pacific, when stacked together come close to this ideal (Cobb et al., 2003, 2013). A com- 


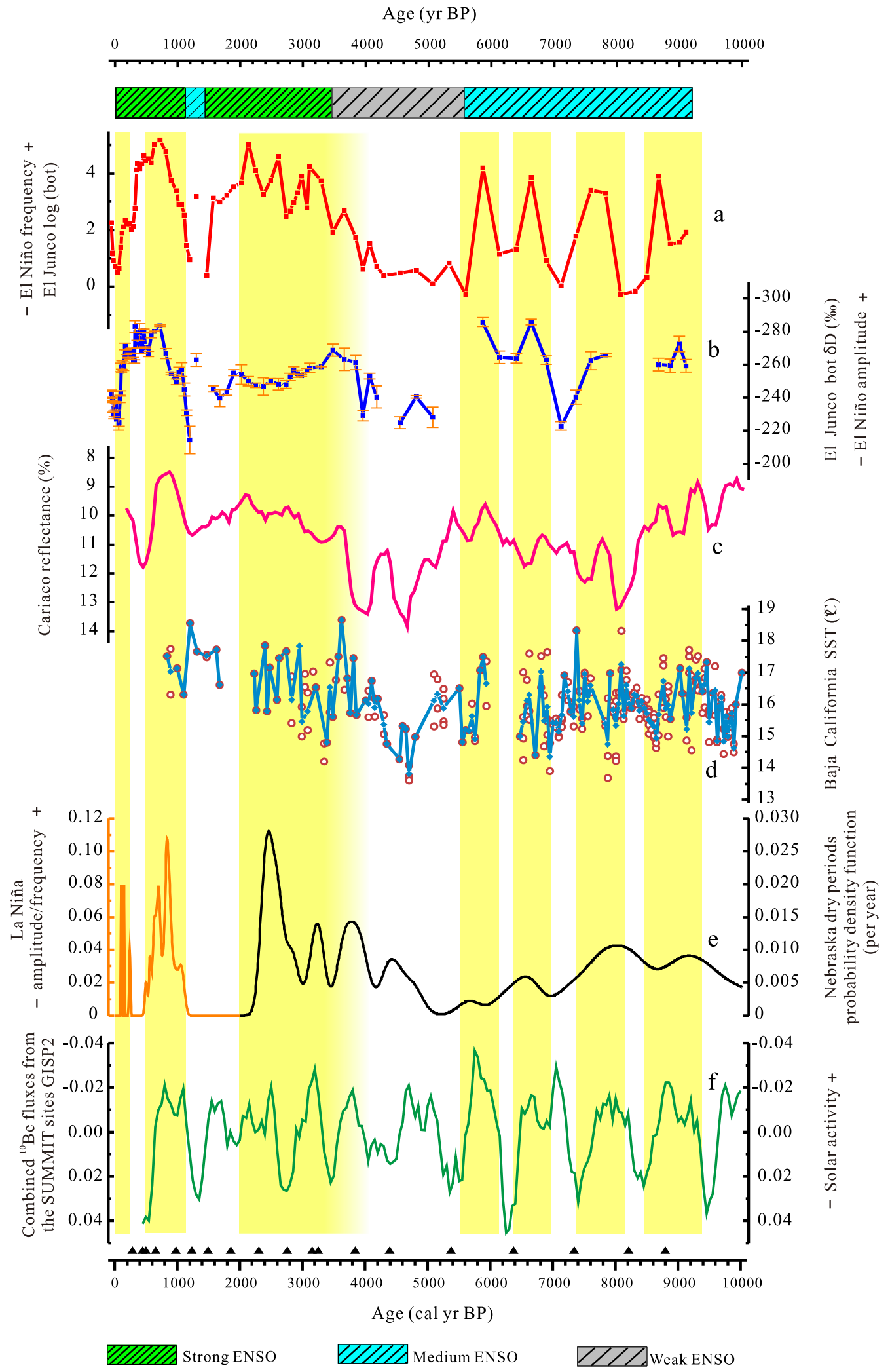

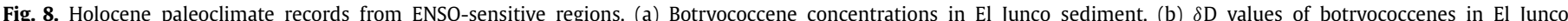

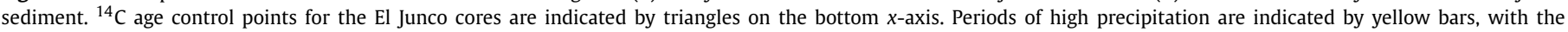

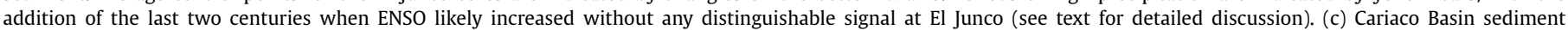

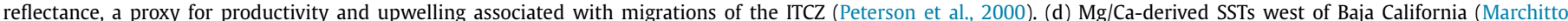

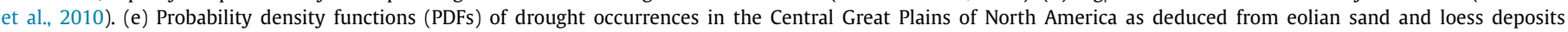

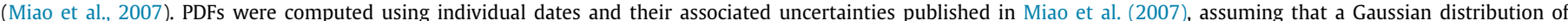

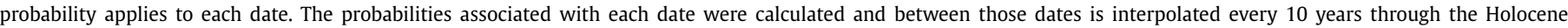

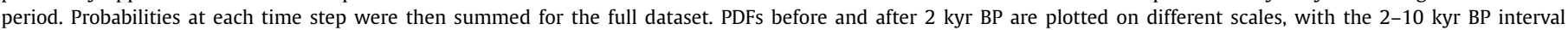

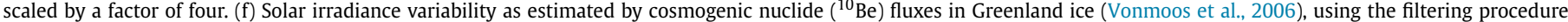
described in Marchitto et al. (2010). 
parison of coral $\delta^{18} \mathrm{O}$ records from Cobb et al. (2013) from the last $7 \mathrm{ka}$ (Fig. 6c) with the El Junco Lake records implies that the latter capture the most prominent features of ENSO activity even though the sediment layers from which they were extracted were deposited over years to decades (compare Fig. 6a, b with c). The near-absence of botryococcenes between 5600 and $3500 \mathrm{yr}$ BP coincides with a time of very low inter-annual variability in the coral records (Cobb et al., 2013; McGregor et al., 2013; Fig. 6). On the other hand, high ENSO variance $\sim 7$ ka recorded by the oldest corals correspond to periods when El Niño, as recorded by botryococcene concentrations and $\delta \mathrm{D}$ values, were comparatively frequent.

Changes in ENSO activity have also been recently estimated from the variance of $\delta^{18} \mathrm{O}$ values in individual planktonic foraminifera from a marine sediment core east of the Galápagos (Koutavas and Joanides, 2012). The early, middle and late Holocene succession of intermediate, low and high ENSO activity, respectively, is recorded in both El Junco proxies and the marine record (Fig. 6a, $\mathrm{b}, \mathrm{d})$. This suggests that both the concentration and $\delta \mathrm{D}$ value of botryococcenes in El Junco sediment capture the low frequency (multi-millennial) variations in ENSO during the Holocene.

\subsection{Coincident changes in Galápagos rainfall, Baja California SST, and Cariaco Basin upwelling during the Holocene}

The precipitation anomalies inferred from botryococcene concentrations and $\delta \mathrm{D}$ values (Figs. 8a, b) in El Junco ultimately depend on SST anomalies in the eastern equatorial Pacific (EEP) through ocean-atmosphere interactions (Gu et al., 2005; Koutavas and Joanides, 2012). During El Niño, positive SST anomalies in the EEP cause increased wind convergence that drives intense convection in the overlying atmosphere, resulting in positive precipitation anomalies (Koutavas and Joanides, 2012; Rasmusson and Carpenter, 1982). These conditions induce atmospheric changes around the globe. The varying modes of ENSO activity we infer from El Junco lake sediments ought therefore to be evident in paleoclimate records from locations with clear connections to the EEP. One such location is the western tropical North Atlantic, where El Niño events are associated with an increase in the strength of the easterly trade winds (Latif and Grötzner, 2000). Located in the heart of the western tropical Atlantic, the Cariaco Basin off the coast of Venezuela is highly sensitive to these ENSO-related trade wind anomalies (Peterson et al., 2000) (Fig. 1a). Increased zonal wind strength during El Niño enhances coastal upwelling there, resulting in greater primary productivity (Taylor et al., 2012). Periods of higher El Niño amplitude and/or frequency are therefore expected to be characterized by greater rainfall in the Galápagos and higher productivity in the Cariaco Basin. We observe such a relationship in the Holocene sedimentary records from the two locations, where sediment reflectance in the Cariaco Basin, a proxy for productivity (lower reflectance reflects greater organic matter in the sediment) (Peterson et al., 2000), share some of the most prominent modes of variability with botryococcene concentrations and $\delta \mathrm{D}$ values in El Junco Lake on the multi-millennial to multi-centennial timescale (Fig. 8a, b, c).

Changes in the annual cycle of insolation may induce changes in wind and rain that can potentially obscure the sedimentary signal associated with ENSO in both the Galápagos and Cariaco Basin. It is therefore important to consider whether changes in seasonality can explain changes in El Junco rainfall and Cariaco productivity. We do this by examining a Holocene SST record from the northeastern tropical Pacific where warm SSTs occur during El Niño events and boreal summers (Figs. 3, 4). The Mg/Ca-derived SST record near Baja California is characterized by alternating extremes of $\pm 2{ }^{\circ} \mathrm{C}$ lasting several centuries during the early Holocene, followed by a relatively colder and less variable period during the mid-Holocene, and relatively warm conditions during the late Holocene (Marchitto et al., 2010) (Fig. 8d). This pattern of SST changes is mirrored in the pattern of rainfall changes inferred from El Junco, which was intermittently very wet and very dry during the early Holocene, dry during the mid-Holocene and primarily wet during the late Holocene (Fig. 8d). Since the boreal summer season is associated with warm SSTs near Baja California and low rainfall in the Galápagos, while the opposite relationship is observed in the sediment record (i.e. warm Baja SSTs coincide with wet conditions at El Junco), we rule out seasonality as the firstorder cause of changes in the two records. Instead we propose that climatic teleconnections associated with ENSO caused coincident changes in Galápagos rainfall, Baja California SST, and Cariaco Basin upwelling during the Holocene, as the comparison of El Junco and the tropical Pacific corals suggests (Fig. 6).

\subsection{Synchronized variations of El Niño and La Niña during the Holocene?}

Because changes in ENSO also depend on the amplitude and frequency of La Niña events, co-variation of ENSO activity proxy records, such as coral and individual foraminifera $\delta^{18} \mathrm{O}$ variance, with the El Niño proxy records from botryococcenes in El Junco, should not necessarily be expected. While most of the dynamic range in precipitation in the Galápagos results from El Niño rains, and no sedimentary archives from the EEP are primarily sensitive to La Niña conditions (the latter being best described as a heightened normal state of the EEP), intense drought conditions on the Great Plains of North America are linked to frequent and strong La Niña events (Trenberth and Guillemot, 1996). A Holocene record of Great Plains drought, and by extension La Niña, can be derived from well-dated sand and loess deposits (Miao et al., 2007). We computed the probability density functions (PDF) of Holocene dry episodes from a database of sediment cores from the Great Plains (Fig. 8e). High values of the PDFs indicate periods when dry conditions linked to recurrent and severe La Niña events were common. Central Great Plains dry periods occurred whenever wetter conditions are inferred from El Junco sediments throughout the Holocene (Fig. 8a, c, e), indicating that periods of strong and frequent El Niño events were also periods of frequent and strong La Niña events. An absence of droughts on the Central Plains (weak La Niña) between 2 and 1 kyr BP was followed by a sharp increase in droughts (strong La Niña) (Fig. 8e), mirroring the pattern of precipitation in the Galápagos, which was dry from 2 to 1 kyr BP and very wet between 1 and $0.5 \mathrm{kyr}$ BP (Fig. 7a, b).

The amplitude and frequency of Central Great Plains dry events prior to $2 \mathrm{kyr}$ BP appears much lower than during the late Holocene (Fig. 7e; PDFs before and after $2 \mathrm{kyr}$ BP are plotted on different scales). We cannot determine whether the low PDF values prior to $2 \mathrm{kyr}$ BP are the result of less severe and frequent La Niña events or non-linearity in the proxy, though we suspect the latter. These data consist of dates on aeolian sand and loess deposits that are erosional features of the surrounding landscape. As with exposure ages from cosmogenic isotopes used to reconstruct glacier advances, this proxy suffers from the fact that, over time, erosion erases geomorphological features. Thus, older deposits that may have been prominent and numerous are much less prominent, or even obliterated, over thousands of years. For this reason we do not attempt to use the amplitude of Nebraska drought variations in our climate interpretation, but only the timing of maxima in the PDFs. Similar timing of those maxima (Fig. 8e) with the timing of botryococcene concentration maxima in El Junco (Fig. 8a) implies that periods of frequent and strong El Niños coincided with periods of frequent and strong La Niñas throughout the Holocene. 


\subsection{Evolution of ENSO during the Holocene and possible driving forces}

A synthesis of our Galápagos precipitation record with periods of drought in the Great Plains and SST in the northeast tropical Pacific indicates that the early, middle and late Holocene were characterized by different modes of ENSO activity. The early Holocene (9200-5600 yr BP) was characterized by a series of rapid changes between periods of strong and weak ENSO activity at the multi-centennial time scale. This contradicts several studies that reported little or no ENSO activity at that time (Moy et al., 2002; Sandweiss et al., 1996). The mid-Holocene (5500-3800 yr BP) was dominated by significantly reduced ENSO activity. The late Holocene was characterized by frequent and strong ENSO activity, with the exception of the 1500-1000 yr BP time interval, when ENSO was substantially reduced.

An increase in the amplitude and/or frequency of ENSO activity from the mid- to the late Holocene has been documented in a multitude of studies. The first-order forcing is thought to be the long-term changes in the Earth's orbit that redistributes solar energy. Virtually all climate models forced by changes in orbital parameters converge toward an orbitally-forced increase in ENSO activity (see e.g. Clement et al., 1999; Emile-Geay et al., 2007; Zheng et al., 2008; Salau et al., 2012; Braconnot et al., 2012 and references therein). Orbital parameters during the mid-Holocene led to an increase in solar heating at the equator during the boreal summer. The zonal temperature response to such heating is, however, not uniform, and produces an increased zonal SST gradient that strengthens the Walker circulation through ocean-atmosphere interactions also known as the Bjerknes feedback (see e.g. Clement et al., 2000). Most models forced by orbital parameters produce a monotonic increase in the strength of ENSO in response to Holocene changes in orbital forcing. Yet none of them produces a Holocene ENSO time series similar to any of the proxy records displayed in Figs. 6 and 8. Taken together, the high sensitivity of ENSO to orbital precession in transient climate simulations, coupled with their inability to produce multi-centennial changes in ENSO implies that certain aspects of the underlying climate physics are not adequately represented in those models.

While changes in ENSO on the multi-millennial timescale have been described in the literature, multi-centennial variability has garnered less attention. It has already been suggested that solar activity can lead to changes in ENSO activity (e.g. Emile-Geay et al., 2007). Co-variations between SSTs near Baja California and reconstructions of solar activity over the last $12 \mathrm{kyr}$ (Vonmoos et al., 2006) suggested that multi-century solar minima were associated with El Niño-like conditions during the early Holocene (Marchitto et al., 2010). We, too, find a visual correspondence between solar activity and ENSO during the Holocene, even though the poorly resolved early Holocene time period and the age model uncertainties complicate the assignment of multi-centennial changes in ENSO to those reflected in solar activity proxies. Broadly speaking, multi-centennial changes in climate proxies sensitive to ENSO suggest that high solar activity (Fig. 8f) coincided with both increased El Niño and La Niña occurrences (e.g., compare Fig. 8a and e to f).

It is clear that not all proxy records shown in Fig. 8 co-vary on the multi-centennial timescale for the entirety of the Holocene. One cause for disagreement between certain proxies at certain times may stem from age model uncertainties and sampling resolution. Another is the differing nature of each type of proxy, with varying contributions from biological, chemical and physical "noise" in the inferred climate signal. A third possibility is that the strength and character of ENSO teleconnections may have changed over time in response to stochastic and other climate forcings. Marchitto et al. (2010) reported that the correspondence between the SST at Baja California and the solar activity was altered during the early Holocene in response to the "8.2-ka event". Consider- ing the above-mentioned sources of uncertainty we refrain from interpreting disparities in the proxy records, particularly at the centennial timescale. We argue instead that features common to multiple records during the early, mid and late Holocene (Figs. 7 and 8 ) are best explained by the changing sensitivity of ENSO to solar and orbital forcings during the Holocene.

During the instrumental period, an association is observed between the 11-yr solar cycle and ENSO (Meehl et al., 2009; Meehl and Arblaster, 2009; van Loon and Meehl, 2011). At the onset of the sunspot maximum, SSTs and rainfall in the EEP are anomalously low, as during La Niña. They are anomalously high two years later, as during El Niño. Furthermore, NINO3.4 SST estimates from Emile-Geay et al. (2013) imply an anti-phasing between EEP SSTs and solar activity at the centennial timescale, suggesting that longer term changes in solar activity trigger an equatorial response analogous to the "ocean thermostat" feedback (Emile-Geay et al., 2013). A visual correspondence between periods of increased solar activity (Fig. 8f) and of both El Niño and La Niña activity (Fig. 8a, b, d and e) supports the existence of a link between ENSO and solar activity on millennial timescales.

Small changes in Total Solar Irradiance (TSI) can be associated with large changes in ultraviolet (UV) radiation, such that a $0.1 \%$ increase in TSI during sunspot maxima coincides with a $\sim 6 \%$ increase in solar UV (Hood, 2004). The higher UV warms the stratosphere directly and stimulates ozone production that further absorbs UV light and intensifies the initial warming, particularly in the tropics where sunlight is most intense. Vertical motion in the tropical troposphere increases in response, which intensifies the ascending limb of the Hadley cell and produces greater precipitation in the ITCZ (Haigh, 1996; Hood and Soukharev, 2012; Meehl et al., 2009; van Loon and Meehl, 2011). In addition, the Hadley cell broadens and the Walker circulation intensifies, resembling Pacific climate anomalies during La Niña events (Hood and Soukharev, 2012; Meehl et al., 2009; van Loon and Meehl, 2011). A second dynamical mechanism by which small changes in TSI can cause changes in ENSO involves greater heating of the clear-sky subtropics during solar maxima, promoting increased evaporation (Meehl et al., 2009). Moisture thus derived is transported by trade winds to the ITCZ where it fuels intensification of the Hadley and Walker circulations, again resulting in La Niña-like conditions (Meehl et al., 2009). Together these two dynamical responses represent a positive feedback at solar maxima driving tropical Pacific temperature and rainfall patterns into an increasingly La Niña-like state. Eventually, eastward-propagating Kelvin waves are spawned that transition the system back toward El Niño-like conditions (Meehl and Arblaster, 2009). Evidence that ENSO variability was enhanced during the relatively stronger 1979-1993 solar cycles compared to the subsequent weaker solar cycles that occurred during the 1994-2009 period supports a causal link between TSI and the tropical Pacific climate (Hood and Soukharev, 2012). Modeling studies of spectral solar irradiance suggest that UV radiation may have been as much as $50 \%$ lower during extended solar minima such as the Maunder minimum, $\sim 1650-1700$ A.D. (Krivova and Solanki, 2005). The possibility thus exists for a large response of the tropical climate to relatively modest changes in TSI. We propose that the same dynamical responses to multi-century periods of high solar activity would cause the coupled increases in El Niño and La Niña activity inferred from the Galápagos and Great Plains records.

\section{Conclusions}

We presented a continuous 9200-year record of rainfall variations from the only permanent freshwater lake in the Galápagos Islands. Changes in the concentration and hydrogen isotope ratio of lipids produced by the green alga Botryococcus braunii (B race), 
which blooms during El Niño rains in the Galápagos, indicate that the early Holocene (9200-5600 yr BP) was characterized by alternating extremes in the intensity and/or frequency of El Niño events that lasted a century or more. Our data from the core of the ENSO region thus refutes earlier studies that reported a lack of El Niño events in the early Holocene. The mid-Holocene (5600-3500 yr $\mathrm{BP})$ was a time of consistently weak El Niño activity, as were the Early Middle Ages ( 1000-1500 yr BP) and the 19th-to-mid-20th centuries. El Niño event strength and frequency were moderate to high during the remainder of the last 3500 years.

Empirical evidence from a diverse set of continuous paleoclimate records make clear that the ENSO mode of climate variability persisted throughout the last 9200 years, except for the period from about 5500-3800 yr BP, when ENSO was weak or inoperative. Synchronous changes in Galápagos rainfall extremes and in the occurrence of US Great Plains drought with cosmogenic nuclide production supports a link between solar activity and ENSO throughout most of the Holocene. These observations can be exploited to improve models being used to predict changes in ENSO caused by anthropogenic climate forcing. Indeed, based on the Holocene evolution of ENSO, we propose it is likely that the future intensity and frequency of both El Niño and La Niña will be at least partly modulated by natural variations in solar activity.

\section{Acknowledgements}

This work is supported by the U.S. National Science Foundation under Grants ESH-0639640 (J.S.) and EAR-0823503 (J.S.); by the Comer Science and Education Foundation (J.S.), and by the Chinese National Science Foundation under grant 41273086 (Z.Z). We thank Rienk Smittenberg, Paul Colinvaux, Jonathan Overpeck, Miriam Steinitz-Kannan and Jessica Conroy for assistance in the field, and to the Galápagos National Park and the Charles Darwin Foundation for their assistance with fieldwork and for their permission to work on El Junco Lake. We are grateful to the constructive reviews from two anonymous reviewers, and to Birgit Schneider for discussions on an earlier version.

\section{Appendix A. Supplementary material}

Supplementary material related to this article can be found online at http://dx.doi.org/10.1016/j.epsl.2014.07.013.

\section{References}

Aaronson, S., Berner, T., Gold, K., Kushner, L., Patni, N.J., Repak, A., Rubin, D., 1983. Some observations on the green planktonic alga, Botryococcus braunii and its bloom form. J. Plankton Res. 5, 693-700.

Appleby, P.G., Oldfield, F., 1978. The calculation of lead-210 dates assuming a constant rate of supply of unsupported ${ }^{210} \mathrm{~Pb}$ to the sediment. Catena $5,1-8$.

Ashok, K., Behera, S.K., Rao, S.A., Weng, H., Yamagata, T., 2007. El Niño Modoki and its possible teleconnection. J. Geophys. Res. 112, C11007. http://dx.doi.org/ 10.1029/2006JC003798.

Atwood, A.R., Sachs, J.P., 2014. Separating ITCZ- and ENSO-related rainfall changes in the Galápagos over the last $3 \mathrm{kyr}$ using $\mathrm{D} / \mathrm{H}$ ratios of multiple lipid biomarkers. Earth Planet. Sci. Lett. 404, 408-419. http://dx.doi.org/10.1016/ j.epsl.2014.07.038.

Belcher, J.H., 1968. Notes on the physiology of Botryococcus braunii Kützing. Arch. Microbiol. 61, 335-346.

Braconnot, P., Luan, Y., Brewer, S., Zheng, W., 2012. Impact of Earth's orbit and freshwater fluxes on Holocene climate mean seasonal cycle and ENSO characteristics. Clim. Dyn. 38, 1081-1092.

Bronk Ramsey, C., 2008. Deposition models for chronological records. Quat. Sci. Rev. 27, 42-60.

Clement, A.C., Seager, R., Cane, M.A., 1999. Orbital control on El Niño/Southern Oscillation and the tropical climate. Paleoceanography 14, 441-456.

Clement, A.C., Seager, R., Cane, M.A., 2000. Suppression of El Niño during the midHolocene by changes in the earth's orbit. Paleoceanography 15, 731-737.

Cobb, K.M., Charles, C.D., Cheng, H., Edwards, R.L., 2003. El Niño-Southern Oscillation and tropical Pacific climate during the last millennium. Nature 424, 271-276.
Cobb, K.M., Westphal, N., Sayani, H.R., Watson, J.T., Lorenzo, E.D., Cheng, H., Edwards, R.L., Charles, C.D., 2013. Highly variable El Niño-Southern Oscillation throughout the Holocene. Science 339, 67-70.

Colinvaux, P.A., 1972. Climate and the Galápagos Islands. Nature 240, 17-20.

Collins, M., et al., 2010. The impact of global warming on the tropical Pacific and El Niño. Nat. Geosci. 3, 391-397.

Conroy, J.L., Overpeck, J.T., Cole, J.E., Shanahan, T.M., Steinitz-Kannan, M., 2008. Holocene changes in eastern tropical Pacific climate inferred from a Galápagos lake sediment record. Quat. Sci. Rev. 27, 1166-1180.

Dansgaard, W., 1964. Stable isotopes in precipitation. Tellus 16, 436-468.

DiNezio, P.N., Clement, A.C., Vecchi, G.A., Soden, B.J., Kirtman, B.P., Lee, S.-K., 2009. Climate response of the equatorial Pacific to global warming. J. Climate 22, 4873-4892.

Emile-Geay, J., Cane, M., Seager, R., Kaplan, A., Almasi, P., 2007. El Niño as a mediator of the solar influence on climate. Paleoceanography 22. http://dx.doi.org/ 10.1029/2006PA001304.

Emile-Geay, J., Cobb, K.M., Mann, M.E., Wittenberg, A.T., 2013. Estimating central equatorial Pacific SST variability over the past millennium. Part II: Reconstructions and implications. J. Climate 26, 2329-2352.

Green, J., Corbet, S.A., Betney, E., 1974. Ecological studies on crater lakes in West Cameroon, Debundsha Lake. J. Zool. (Lond.) 173, 199-223.

Gu, G.J., Adler, R.F., Sobel, A.H., 2005. The Eastern Pacific ITCZ during the boreal spring. J. Atmos. Sci. 62, 1157-1174.

Haigh, J.D., 1996. The impact of solar variability on climate. Science 272, 981-984

Hood, L.L., 2004. Solar variability and its effect on the Earth's atmospheric and climate system. AGU, Washington, DC, pp. 283-303.

Hood, L.L., Soukharev, B.E., 2012. The lower-stratospheric response to 11-yr solar forcing: coupling to the troposphere-ocean response. J. Atmos. Sci. 69, 1841-1864.

Kebede, E., Belay, A., 1994. Species composition and phytoplankton biomass in a tropical African lake (Lake Awassa, Ethiopia). Hydrobiologia 288, 13-32.

Kessler, W.S., 2006. The circulation of the eastern tropical Pacific: a review. Prog. Oceanogr. 69, 181-217.

Koutavas, A., Joanides, S., 2012. El Niño-Southern Oscillation extrema in the Holocene and Last Glacial Maximum. Paleoceanography 27. http://dx.doi.org/ 10.1029/2012PA002378.

Krivova, N.A., Solanki, S.K., 2005. Reconstruction of Solar UV irradiance. Adv. Space Res. 35, 361-364.

Kurita, N., Ichiyanagi, K., Matsumoto, J., Yamanaka, M.D., Ohata, T., 2009. The relationship between the isotopic content of precipitation and the precipitation amount in tropical regions. J. Geochem. Explor. 102, 113-122.

Latif, M., Grötzner, A., 2000. The equatorial Atlantic oscillation and its response to ENSO. Clim. Dyn. 16, 213-218.

Leduc, G., Vidal, L., Cartapanis, O., Bard, E., 2009a. Modes of Eastern Equatorial Pacific thermocline variability: implications for ENSO dynamics over the last glacial period. Paleoceanography 24. http://dx.doi.org/10.1029/2008PA1701.

Leduc, G., Vidal, L., Tachikawa, K., Bard, E., 2009b. ITCZ rather than ENSO signature for abrupt climate changes across the tropical Pacific? Quat. Res. 72, 123-131.

Liu, W.T., Xie, X., 2002. Double intertropical convergence zones-a new look using scatterometer. Geophys. Res. Lett. 29. http://dx.doi.org/10.1029/2002GL015431.

Locarnini, R.A., Mishonov, A.V., Antonov, J.I., Boyer, T.P., Garcia, H.E., Baranova, O.K., Zweng, M.M., Johnson, D.R., 2010. World Ocean Atlas 2009, Vol. 1: Temperature. In: Levitus, S. (Ed.), NOAA Atlas NESDIS, vol. 68. U.S. Government Printing Office, Washington, DC. 184 pp.

Marchitto, T.M., Muscheler, R., Ortiz, J.D., Carriquiry, J.D., van Geen, A., 2010. Dynamical response of the tropical Pacific Ocean to solar forcing during the Holocene. Science 330, 1378-1381.

McCormac, F.G., et al., 2004. Radiocarbon Calibration from 0-26 cal kyr BPSHCa104 Southern Hemisphere Calibration, 0-11.0 cal kyr BP. Radiocarbon 46, 1087-1092.

McGregor, H.V., Fischer, M.J., Gagan, M.K., Fink, D., Phipps, S.J., Wong, H., Woodroffe, C.D., 2013. A weak El Niño/Southern Oscillation with delayed seasonal growth around 4,300 years ago. Nat. Geosci. 6, 949-953.

Meehl, G.A., Arblaster, J.M., 2009. A lagged warm event-like response to peaks in solar forcing in the Pacific region. J. Climate 22, 3647-3660.

Meehl, G.A., Arblaster, J.M., Matthes, K., Sassi, F., van Loon, H., 2009. Amplifying the Pacific climate system response to a small 11-year solar cycle forcing. Science $325,1114-1118$.

Metzger, P., Casadevall, E., Pouet, M.J., Pouet, Y., 1985. Structures of some botryococcenes-branched hydrocarbons from the B-race of the green alga Botryococcus braunii. Phytochemistry 24, 2995-3002.

Miao, X., Mason, J.A., Swinehart, J.B., Loope, D.B., Hanson, P.R., Goble, R.J., Liu, X., 2007. A 10,000 year record of dune activity, dust storms, and severe drought in the central Great Plains. Geology 35, 119-122.

Moy, C.M., Seltzer, G.O., Rodbell, D.T., Anderson, D.M., 2002. Variability of El Niño/Southern Oscillation activity at millennial timescales during the Holocene epoch. Nature 420, 162-165.

Pascolini-Campbell, M., Zanchettin, D., Bothe, O., Timmreck, C., Matei, D., Jungclaus, J.H., Graf, H.-F., 2014. Toward a record of Central Pacific El Niño events since 1880. Theor. Appl. Climatol. http://dx.doi.org/10.1007/s00704-014-1114-2. 
Peterson, L.C., Haug, G.H., Hughen, K.A., Rohl, U., 2000. Rapid changes in the hydrologic cycle of the tropical Atlantic during the last glacial. Science 290, 1947-1951.

Pierrehumbert, R.T., 2000. Climate change and the tropical Pacific: the sleeping dragon wakes. Proc. Natl. Acad. Sci. USA 97, 1355-1358.

Pryet, Domínguez C, A., Tomai, P.F., Chaumont, C., d’Ozouville, N., Villacís, M., Violette, S., 2012. Quantification of cloud water interception along the windward slope of Santa Cruz Island, Galápagos (Ecuador). Agric. For. Meteorol. 161, 94-106.

Rasmusson, E.M., Carpenter, T.H., 1982. Variations in tropical sea surface temperature and surface wind fields associated with the Southern Oscillation/El Niño. Mon. Weather Rev. 110, 354-384.

Richerson, P.J., Neale, P.J., Wurtsbaugh, W., Alfaro, R., Vincent, W., 1986. Patterns of temporal variation in Lake Titicaca - a high-altitude tropical lake. 1. Background, physical and chemical processes, and primary production. Hydrobiologia 138, 205-220.

Risi, C., Bony, S., Vimeux, F., 2008. Influence of convective processes on the isotopic composition $\left(\delta^{18} \mathrm{O}\right.$ and $\left.\delta \mathrm{D}\right)$ of precipitation and water vapor in the tropics: 2. Physical interpretation of the amount effect. J. Geophys. Res. 113. http://dx.doi.org/10.1029/2008JD009943.

Sachs, J.P., Sachse, D., Smittenberg, R.H., Zhang, Z.H., Battisti, D.S., Golubic, S., 2009. Southward movement of the Pacific intertropical convergence zone AD 1400-1850. Nat. Geosci. 2, 519-525.

Salau, O.R., Schneider, B., Park, W., Khon, V., Latif, M., 2012. Modeling the ENSO impact of orbitally induced mean state climate changes. J. Geophys. Res. 117, C05043. http://dx.doi.org/10.1029/2011JC007742.

Sandweiss, D.H., Richardson, J.B., Reitz, E.J., Rollins, H.B., Maasch, K.A., 1996. Geoarchaeological evidence from Peru for a 5000 years BP onset of El Niño. Science 273, 1531-1533.

Steinitz-Kannan, M., Riedinger, M.A., Last, W., Brenner, M., Miller, M.C., 1998. A 6000-year record of intense evidence of El Niño from sediments in a Galápagos Islands lake. Bull. Inst. Fr. Études Andines 27, 581-592 (in Spanish with English abstract).

Taylor, G.T., et al., 2012. Ecosystem responses in the southern Caribbean Sea to global climate change. Proc. Natl. Acad. Sci. USA 109, 19315-19320.

Thirumalai, K., Partin, J.W., Jackson, C.S., Quinn, T.M., 2013. Statistical constraints on the El Niño Southern Oscillation reconstructions using individ- ual foraminifera: a sensitivity analysis. Paleoceanography 28. http://dx.doi.org/ 10.1002/palo.20037.

Townsend, S.A., 2001. Perennial domination of phytoplankton by Botryococcus and Peridinium in a discontinuously polymictic reservoir (tropical Australia). Arch. Hydrobiol. 151, 529-548.

Trenberth, K.E., Guillemot, C.J., 1996. Physical processes involved in the 1988 drought and 1993 floods in North America. J. Climate 9, 1288-1298.

Trueman, M., d'Ozouville, N., 2010. Characterizing the Galápagos terrestrial climate in the face of global climate change. Galápagos Res. 67, 26-37.

van Loon, H., Meehl, G.A., 2011. The average influence of decadal solar forcing on the atmosphere in the South Pacific region. Geophys. Res. Lett. 38. http://dx.doi.org/ 10.1029/2011GL047794.

Vonmoos, M., Beer, J., Muscheler, R., 2006. Large variations in Holocene solar activity: constraints from ${ }^{10} \mathrm{Be}$ in the Greenland Ice Core Project ice core. J. Geophys. Res. 111. http://dx.doi.org/10.1029/2005JA011500.

Wake, L.V., Hillen, L.W., 1980. Study of a bloom of the oil-rich alga Botryococcus braunii in the Darwin River Reservoir. Biotechnol. Bioeng. 22, 1637-1656.

Zhang, Z.H., Sachs, J.P., 2007. Hydrogen isotope fractionation in freshwater algae: I Variations among lipids and species. Org. Geochem. 38, 582-608.

Zhang, Z.H., Metzger, P., Sachs, J.P., 2007. Biomarker evidence for the co-occurrence of three races (A, B and L) of Botryococcus braunii in El Junco Lake, Galapágos. Org. Geochem. 38, 1459-1478.

Zhang, Z., Sachs, J.P., Marchetti, A., 2009. Hydrogen isotope fractionation in freshwater and marine algae: II. Temperature and nitrogen limited growth rate effects. Org. Geochem. 40, 428-439.

Zhang, Z.H., Metzger, P., Sachs, J.P., 2011. Co-occurrence of long-chain diols, keto-ols, hydroxy acids and keto acids in recent sediments of Lake El Junco, Galápagos Islands. Org. Geochem. 42, 823-837.

Zhang, Z.H., Metzger, P., Sachs, J.P., 2013. Unprecedented long-chain 1-chloroalkenes and 1-chloroalkanes in the Holocene sediments of Lake El Junco, Galápagos Islands. Org. Geochem. 57, 1-6.

Zhang, Z.H., Metzger, P., Sachs, J.P., 2014. Bound lipid biomarkers in sediments from El Junco Lake, Galápagos Islands. Org. Geochem. 75, 122-128.

Zheng, W., Braconnot, P., Guilyardi, E., Merkel, U., Yu, Y., 2008. ENSO at 6 ka and 21 ka from ocean-atmosphere coupled model simulations. Clim. Dyn. 30, 745-762. 